\title{
Avances de la Ciencia de Policía en América LATINA
}

\author{
Jairo Enrique Suárez Alvarez \\ Investigador Centro de Pensamiento Policial - Colombia.

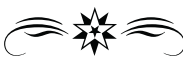

\begin{abstract}
RESUMEN
El objetivo del artículo es hacer una descripción sobre la ciencia de policía en América Latina. Para este propósito el texto se estructura en seis puntos. En los dos primeros se expone el concepto de "ente policía" -transversal a todo el documento- entendido como un fenómeno históricopolítico de naturaleza cívico-estatal, con sentidos y dimensiones, y en principio, concebido como objeto de la ciencia policial. En el punto 3 se esboza el origen de la ciencia de policía en el mundo español y latinoamericano dentro del contexto cambiante de los siglos XVII y XIX. El punto 4 alude a los estudios sobre policía en la región, los cuales se diferencian de los estudios explícitos de ciencia policial (punto 5). El artículo culmina con la posición del autor, la cual plantea y sintetiza la relación entre filosofía política y ciencia de policía, eje fundamental para el futuro desarrollo de una ontología y gnoseología policiales. Al respecto, deja abierto el debate sobre las posibilidades y los alcances prácticos del nuevo saber científico para resolver los problemas humanos que afectan la convivencia. ¿Es acaso posible una nueva ciencia política y social comprometida con las transformaciones necesarias y suficientes que requieren las sociedades actuales y futuras? Este el interrogante que articula los diferentes tópicos a continuación expuestos.
\end{abstract}

\section{Origen del Fenómeno ente Policía}

Como punto de partida este artículo plantea qué se entiende por "ente policía", su naturaleza, los sentidos que implica y su origen a través de referentes históricos enmarcados en las culturas griega y romana, nichos de la civilización occidental ${ }^{1}$. La descripción facilita comprender las razones por las cuales el ente se sustenta como objeto de la ciencia de policía, cuyo contexto ineludible es el denominado Sacro Imperio Romano-Germánico, o de

1 Este estudio se limita al fenómeno policial de las sociedades del mundo occidental (Europa, América...). El mundo oriental y otras regiones planetarias como Asia, África, Oceanía pueden ser objeto de otra investigación. 
modo simple, la región de Alemania de los siglos XVI, XVII y XVIII. La razón de elegir este referente es porque sólo en la Alemania del siglo XVIII, se planteó explícitamente por primera vez y de modo sistemático, la pretensión de una "ciencia de la policía" (Polizeiwissenschaft), también conocida como "ciencia del Estado" y desarrollada por el movimiento Cameralista en cabeza de Jhohann Heinrich Gottlob von Justi, autor de "Elementos generales de policía” publicación de 1756 (Grundsätze der Policeywissenschaft).

Sin esquivar las críticas y polémicas de centrar exclusivamente el origen de la ciencia policial en la región Germana, la tesis inicial del presente trabajo sostiene que, aunque el concepto de policía es anterior al siglo XVIII, es la configuración del Estado moderno liberal en el siglo XIX la que imprime la naturaleza de aquello que se llama "policía" en el mundo actual. En otras palabras, el origen del fenómeno policial es simultáneo al origen del Estado: existe policía en la medida que existe Estado, aunque pueda existir cierto tipo de Estado sin policía. Ahora bien, ¿̇a qué tipo de Estado y a qué tipo de policía se hace referencia? Para responder esta pregunta es necesario precisar qué es cada cosa.

En primer lugar, respecto a qué se entiende por Estado hay dos caminos: primero, entender cómo era la organización social de la especie humana antes de la existencia de la forma "Estado", y segundo, cómo el aumento de la complejidad civilizatoria estructuró aquello que se denomina "Estado"2. En este sentido el profesor Bernd Marquardt (2007: 6) plantea las etapas de la organización política de las sociedades humanas desde dos grandes tipos de complejidad: la preestatal ${ }^{3}$ y la estatal, como se aprecia en el siguiente Cuadro. La columna "Génesis del fenómeno Ente policía” (no es de Marquardt) se adiciona para inferir tal origen.

Marquardt retoma cuidadosamente el concepto clásico de George Jellinek (1851 - 1911), quien entiende por Estado "el cuerpo equipado con el poder soberano originario de un pueblo sedentario", es decir, el dominio sobre el territorio y la gente, en el que tres elementos, concretamente (1) el territorio estatal delimitado, (2) el pueblo de la sociedad individualizada y (3) el poder estatal soberano, forman un sistema político denso. Jellinek -sostiene Marquardt - describe acerta-

2 "A favor de los orígenes del Estado en el siglo XVI se puede argumentar que las raíces del término "Estado" para la denominación de Reinos y repúblicas, aparecen en esta época en las lenguas romances en el sur de Europa. En los siglos precedentes habían sido usuales expresiones como dominio, Imperio o Reino, y también después seguirían siendo utilizadas paralelamente al término "Estado" por mucho tiempo" (Marquardt 2007: 4).

3 "La preestatalidad no debe confundirse con la ausencia de una organización social, pues ya en la época preestatal el grado de organización social tenía desarrollos marcados. Lo que sucede es que no existía ningún liberalismo originario de individuos dispersos, como el que afirmó la teoría del derecho natural de la ilustración" (Marquardt 2007: 9). 
damente un tipo particular de Estado, el de la sociedad de masas individualizada, basado en el pensamiento de la ilustración europea, que se ha expandido por todo el mundo desde la transición del siglo XVIII al XIX" (Marquardt 2007: 3).

No obstante, Marquardt por su parte, plantea un interesante concepto de Estado bastante identificado con el fin de la ciencia policial: "Como común denominador se puede entender por Estado una organización jurídico-política supralocal que coordina la convivencia en el interior y brinda protección contra el exterior. En consecuencia -continúa-, el antónimo de Estado en sus diferentes formas de aparición es solamente la "sociedad preestatal", es decir, aquella forma social que aún no ha conocido ninguna organización política compleja” (Marquardt 2007: 5 - negrilla no del original). Con relación al objeto de la ciencia mencionada, este concepto de Estado es el más aproximado y relacionado con el fenómeno ente policía, según su naturaleza racional y administrativa propia de la acción estatal.

Cuadro: Aumento de la complejidad civilizatoria y etapas de la organización política

\begin{tabular}{|c|c|c|c|}
\hline Tipo & $\begin{array}{c}\text { Etapas Historia DeL } \\
\text { Estado }\end{array}$ & Fases Y Transiciones & $\begin{array}{l}\text { "GÉNESIS DEL FENÓ- } \\
\text { MENO ENTE POLICÍA" }\end{array}$ \\
\hline \multirow{2}{*}{ 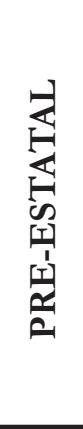 } & $\begin{array}{l}\text { 1. CAZADORES Y RECOLECTORES } \\
\text { - Sistema de energía solar no mo- } \\
\text { delado. } \\
\text { - Al menos dos millones de años }\end{array}$ & Grupos móviles pequeños & \multirow{2}{*}{$\begin{array}{l}\text { Regulación primitiva de } \\
\text { la convivencia: resolución } \\
\text { informal de conflictos, me- } \\
\text { diante el "Consejo de los an- } \\
\text { cianos"= primera institución } \\
\text { política de la historia univer- } \\
\text { sal (según Marquardt) }\end{array}$} \\
\hline & $\begin{array}{l}\text { 2. Sociedades Agrarias Sim- } \\
\text { PLES } \\
\text { - Sistema de energía solar modelado } \\
\text { con leña como transmisor primario } \\
\text { de energía (renovable). } \\
\text { - Desde aprox. } 10.000 \text { a. C. }\end{array}$ & $\begin{array}{l}\text { 1 Fase: Comunidades Locales } \\
\text { ("Tribus") } \\
\text { 2a Fase: Jefaturas Tribales Lo- } \\
\text { CAles }\end{array}$ & \\
\hline \multirow[t]{2}{*}{ 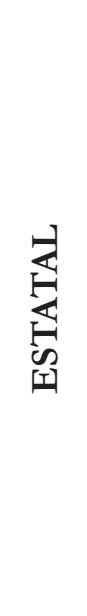 } & $\begin{array}{l}\text { 3. Civilizaciones AgRaRias } \\
\text { Complejas } \\
\text { - Sistema de energía solar modelado } \\
\text { con leña como transmisor primario } \\
\text { de energía (renovable). } \\
\text { - Grado elevado de complejidad. } \\
\text { - Desde aprox. } 3.000 \text { a. C. }\end{array}$ & 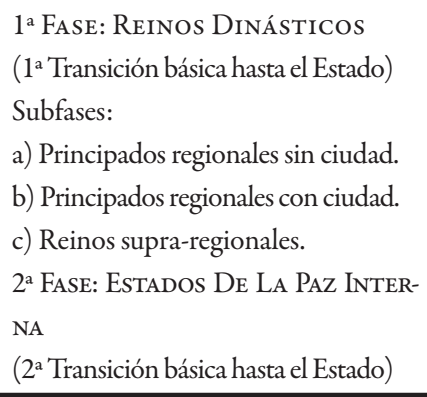 & $\begin{array}{l}\text { Regulación formal de la con- } \\
\text { vivencia sin Ente policía } \\
\text { Regulación formal y siste- } \\
\text { mática de la convivencia con } \\
\text { Ente policía: ciencia de la } \\
\text { policía en Alemania, Francia } \\
\text { y España siglo XVIII }\end{array}$ \\
\hline & $\begin{array}{l}\text { 4. Culturas Industriales } \\
\text { - Sistema de energía fósil (cantidad } \\
\text { creciente, pero no renovable). } \\
\text { - Desde aprox. } 1.800 \text { d. C. }\end{array}$ & $\begin{array}{l}3^{\mathrm{a}} \text { Transición básica de la historia del } \\
\text { Estado. } \\
\text { a) Revolución de la soberanía } \\
\text { b) Estado constitucional republica- } \\
\text { no-democrático }\end{array}$ & $\begin{array}{l}\text { Regulación formal de la } \\
\text { convivencia a través de Ente } \\
\text { policía: derecho público - } \\
\text { administrativo siglo XIX }\end{array}$ \\
\hline
\end{tabular}

Fuente: a partir de Bernd Marquardt (2007: 6). La columna "génesis del fenómeno ente policía" no es del original 
En segundo lugar, en cuanto a qué se entiende con la palabra policía, también hay dos alternativas, una amplia y otra delimitada. En la primera "policía” es un concepto jurídico-político cuyo significado se refiere a la regulación del comportamiento humano mediante la reglamentación de las costumbres por medio de sistemas normativos, la concepción administrativa de la vida social y el manejo de los asuntos públicos. En la segunda, "policía" se relaciona con los cuerpos, instituciones u organizaciones policiales que cotidianamente trabajan en las calles de cualquier ciudad civilizada.

En consecuencia, para la definición del "ente policía" como objeto de la ciencia policial y punto de partida de este trabajo, inicialmente se aborda el primer concepto jurídico-político, y de esta forma se describe la génesis y metamorfosis del fenómeno ente policía. En el Cuadro a partir del planteamiento de Marquardt, es posible afirmar luego, que el "ente policía" -en su versión formal y sistemática- aparece en la segunda $2^{\text {a }}$ Fase: Estados de la paz interna. En particular, en Alemania, Francia y España desde el siglo XV aproximadamente, hasta el siglo XVIII, se ubica tal génesis.

Sin embargo, al respecto, Marquardt advierte lo siguiente: "En los siglos XVI hasta el XVIII permaneció completamente ausente la subdisciplina clave de la administración moderna, es decir, la administración policial. Aunque existieron abundantes leyes de la "buena policía" en todos los niveles de poder para la regulación del comportamiento cristiano-moral de la población, que fue visto como altamente relevante para la salvación eterna, no existió ninguna policía en el sentido institucional. El deber de ejecutar las leyes de la "buena policía" fue delegado a los poderes tradicionales del segmentarismo, que también continuaron autónomamente en la lucha contra el crimen con su propia milicia de campesinos, sus mecanismos de autorregulación en sistemas sociales pequeños y algunos guardias, por ejemplo para cuidar sus fuentes energéticas, los bosques". - Y continúa- : "Debido a que el Estado de la paz interna fue diseñado como un Estado judicial, en el cual los fallos de cortes de justicia reemplazaron las guerras interlocales, la construcción de la organización judicial en todo el territorio fue el elemento clave de la intensificación organizacional” (Marquardt 2007: 227 - 228 Negrilla no del original). Es entonces con la aparición de las "Culturas industriales" (Ver Cuadro 1), que la revolución de la soberanía y el Estado constitucional republicano-democrático cambió la configuración del ente policía, diluido en el derecho público-administrativo del siglo XIX.

De lo anterior queda claro, que policía es una noción amplia que va más allá de la idea de cuerpo-institución, y como tal, para la historia de la cien- 
cia policial, representa un concepto clave con intensa afinidad a la estructuración política de los Estados y los asuntos de gobierno. Es así como la expresión ente policía es apropiada para tratar los fenómenos de la organización social.

\section{Naturaleza y Sentidos del ente Policía}

\section{I QUÉ SIGNIFICA “ENTE POLICÍA”}

Según lo antes expuesto, aquello que actualmente se denomina "policía" es el resultado de un largo proceso histórico de cambios y transformaciones, respecto a un fenómeno crucial que influyó decisivamente en lo que fueron, y llegaron a convertirse, las sociedades del mundo occidental. En consecuencia, para entender la pluralidad de significados y connotaciones que la palabra "policía" contiene a través de la historia, un acertado punto de partida para abordar este término, es concebirlo inicialmente, como un complejo fenómeno histórico-político denominado "ente policía".

En este sentido, cuando se habla del "ente policía", se plantea el estudio de tal fenómeno en cuanto a la esencia de su ser, es decir, desde el punto de vista universal, como totalidad y unicidad: es necesario luego -sostiene Londoño- "...identificar sus características, peculiaridades, categorías, fenómenos, y sus propiedades particulares y específicas” (Londoño C. Fabio A 2007, 87). En otras palabras, se trata en adelante, de identificar y analizar aquello que hace que la policía sea policía y no otra cosa, aunque simultáneamente, ella sea una y diversas cosas a la vez $z^{4}$. En síntesis, ente policía significa el ser y los modos de ser del fenómeno policial el cual posee diversos sentidos y dimensiones.

\subsection{SENTIDOS Y DIMENSIONES DEL ENTE POLICÍA}

Para organizar los diferentes significados que el concepto de ente policía implica y ha tenido a través del tiempo, a continuación se plantean

4 La palabra "ente" en filosofía, corresponde a uno de los términos abstractos para hacer referencia al estudio del ser de las cosas (ontología), y en cuanto a su esencia y su existencia (metafísica). Más allá de las discusiones que acarrea dicho término, su uso se puede dar en tres sentidos: en sentido unívoco (algo es lo que es), en sentido multívoco (algo es varias cosas), y en sentido equívoco (algo no es preciso lo que es). Finalmente, "si el ente es todo lo que es o puede ser, habrá que precisar de qué distintos modos se dice de algo que es ente. Por ejemplo, puede dividirse el ente en: "ente real" y "ente de razón"; “ente potencial” y “ente actual”, y éste último en "esencia y existencia” (Ferrater Mora 1994, 1024). 
tres sentidos en que puede ser objeto de investigación de la ciencia policial: multívoco, equívoco y unívoco, de los cuales este estudio hace énfasis en el tercero sin desconocer los precedentes.

\section{a) Sentido multívoco del ente policía}

Policía es una palabra polisémica o referente a múltiples significados y connotaciones. Sólo a modo descriptivo es posible identificar los siguientes campos de significación del ente policía, unos combinados con otros y en algunos casos, muy afines entre sí.

- Significado político: relacionado con las nociones de orden, organización social, Estado, gobierno, poder y régimen, entre las principales.

Originariamente el ente policía es asociado a un sentido político de cuyas palabras clave "orden" es esencial, y se adhieren a él poder, gobierno y régimen. Pero acá no se alude a "política" en sentido banal, sino a una visión filosófica del pensamiento político que clasifica según la ideología bien sea liberal democrática, republicana, comunitaria..., el tipo de Estado y de concepción de policía que ostenta una sociedad. De ello se puede colegir, por ejemplo, que según el tipo ideológico de Estado así es también la noción de policía, tanto como institución como forma de gobernar (regulativa, coactiva, coercitiva, disuasiva, persuasiva...)

- Significado jurídico: relacionado con las nociones de derecho, cumplimiento de la ley, doctrina, reglamentación, regulación y función, especialmente.

El ente policía se fundamenta en el orden jurídico, y sin éste, no tiene existencia ni sustento de legitimidad. El derecho de policía es la primera expresión científica del ente como disciplina social. Las relaciones sociales son reguladas por la función policial a través de la doctrina, sus principios, sus leyes y la normatividad que reglamenta la vida en sociedad. En muchos contextos "policía" es sinónimo de "ley" y de "justicia" aplicada en las calles 5 . Además la función policial es considerada como el primer eslabón en los procesos de judicialización en el marco del Estado legislador.

5 Como en el libro titulado "Justicia en la calle: ensayos sobre la policía en América Latina" de Peter Waldmann (1996). 
- Significado ético-deontológico: relacionado con la idea de principios y virtudes, y sentido de pertenencia a una institución policial.

El ente policía implica y exige un significado relacionado con las virtudes y los principios que debe poseer y practicar quien pertenece a una institución policial, e incluso quienes regulan, administran y ejecutan la función de policía. Policía significa persona civilizada guiada por un código axiológico que orienta su acción hacia el comportamiento favorable a la convivencia, más por convicción y principio que por obligación, en cuanto se aceptan los deberes y derechos de compartir la vida con otros.

- Significado administrativo: relacionado con institución, organización, y cuerpo burocrático.

El ente policía es entendido como un conjunto de instituciones que regula, administra y ejecuta la función policial. Como parte del aparato estatal, el ente policía se expresa en diferentes niveles de la administración pública, bien sea en el nivel ejecutivo, en la rama legislativa y de alguna forma en el sistema judicial. Como cuerpo institución, el ente policía es identificado como parte de la organización burocrática de un Estado y fuerza de administración policial.

- Significado en la gestión pública: relacionado con las ideas de actividad pública, servicio de vigilancia, gestión policial, y recientemente gerencia de la seguridad.

El ente policía desde la gestión pública es concebido como el Estado en acción, esto es, aquella función obligatoria que tiene un gobierno de prestar "un servicio público" de vigilancia (entre otras actividades) para garantizar la seguridad física de las personas, en cuanto a la protección de la vida, sus bienes materiales y la preservación de cierto orden y disciplina social. En este sentido, el ente policía se concibe más como ejecutor de la política pública preva-

6 Londoño Cárdenas (2007: 197) junto a Canasi (1976) y Serrá Rojas (1972), no está de acuerdo en considerar la función pública del ente policía como "servicio público". La razón consiste en que el "régimen de policía es una actividad administrativa encaminada a crear el clima propicio para el desarrollo nacional, que demanda una convivencia pacífica y ordenada, mientras "el servicio público" se traduce en prestaciones concretas en relación con las necesidades de los particulares”. Es decir, para Londoño resulta de suma gravedad y riesgo calificar de "servicio público" la función de policía, porque esto conlleva degeneración en tratar a las personas como "clientes" - por ejemplo- y desviar tanto los medios como el fin del ente policía: el trato humano hacia la convivencia. 
leciente en un momento dado. Entre tanto, el reto está en la forma cuantitativa y cualitativa de medir la gestión policial del ente, con base en las necesidades y demandas de la sociedad.

- Significado cultural: relacionado con institución mítica, lucha contra el crimen y la delincuencia.

El ente policía adquiere su modo de ser según la cultura a la cual pertenece. Él es producto directo de la cultura. Por cultura se entiende aquella creación de significaciones, instituciones y conductas por medio de la cual los seres humanos intentan suplir sus carencias naturales y sus deficiencias instintivas. En este sentido, culturalmente la policía ha sido concebida como una "institución mítica", según la creencia dominante de que ella es la solución de casi todos los problemas de una sociedad, y se le sobrecarga toda la responsabilidad de acabar el crimen y la delincuencia. Según las representaciones mentales o los imaginarios sociales se cree que con policía se soluciona todo, o casi toda alteración de la tranquilidad y de la convivencia.

- Significado teleológico: relacionado con convivencia, seguridad, paz, bienestar, calidad de vida, y desarrollo humano.

El ente policía posee un significado según el fin que se le otorgue o de acuerdo a la expectativa que una sociedad tiene de él. No obstante, dicho fin dependerá de la madurez cultural de tal sociedad y del conjunto de significaciones que la orienten o gobiernen. Así, algunas sociedades harán más énfasis en la seguridad mientras para otras será más importante la paz, la convivencia o el desarrollo humano en general. En la actualidad se concibe el ente policía asociado fuertemente a la idea de seguridad, cuando en realidad su eje central y su fin último es la convivencia.

- Significado ecológico: relacionado con protección, vigilancia, control y cuidado de recursos naturales, salubridad y antiguamente ornato e higiene pública.

Una tendencia inevitable del ente policía en el siglo XXI es y será

7 Diego Torrente Robles (1999) en "Prevención del delito y futuro de la policía" plantea la idea de la policía como institución mítica, pues en la literatura, el cine y los medios de comunicación ella ha sido retratada bajo la creencia arraigada de contener la delincuencia aplicando la ley. También David Bayley (1994) en "Police for the future" hace esa sugestiva connotación del ente policía. 
el aumento de la conciencia ecológica. La relación entre el ser humano y la naturaleza es determinante en los procesos sociales: la convivencia se puede afectar en la medida que los individuos entren en conflicto por los recursos naturales no renovables de los que depende su subsistencia, el agua, las fuentes de energía, el territorio, la biodiversidad, entre otros elementos. Adicional a ello, el deterioro ambiental en las grandes ciudades por causa de la contaminación, o los atentados contra la riqueza natural, demandan la acción policial cuando los efectos negativos son o no intencionales o producidos por el mismo ser humano (antrópicamente).

- Significado práctico: relacionado con función, actividad, servicio, proceso, fuerza, control, estructura operativa, regulación, intervención, prevención, disuasión, mediación, precautelación, anticipación, acción prospectiva, disciplina, comunicación y pedagogía social. Finalmente, todas estas son connotaciones posibles con las cuales se relaciona el ente policía desde el punto de vista pragmático ${ }^{8}$. Este es un significado dominante y exigente para el desarrollo de la ciencia policial, porque se espera de ella aportes a la dinámica inmediatista y respuestas efectivas frente a la emergencia de nuevas formas de delincuencia y criminalidad. Sin embargo, entre tanto, es importante resaltar las funciones de comunicación y pedagogía sociales que cumple el ente policía: las organizaciones policiales del siglo XXI deben intensificar estrategias prácticas de administración de tecnologías de la información y la comunicación, así como aumentar su función educativa y pedagógica del comportamiento social favorable a la convivencia.

\section{b) Sentido equívoco del ente policía}

Consiste en aquella desviación negativa y peyorativa del ente policía. Al igual que muchas instituciones humanas, históricamente la policía ha padecido tergiversaciones respecto al fin originario para el cual fue creada. Desde este punto de vista, las connotaciones que siguen corresponden al no-deber-ser, o a todo

8 Todas estas connotaciones se mencionan directa e indirectamente en lo sucesivo. Sin embargo, desde el punto de vista de la doctrina del derecho de policía en Colombia, el profesor Roberto Pineda, alude, entre otras definiciones, a la policía como "una institución civil de gobierno (...)", y expresa que "la actividad de Policía es cambiante o movediza según los tiempos históricos (...); que es una actividad "problemática”, y sobre todo, que "la actividad de policía es compleja. Tiene varias maneras de manifestarse. Es poder, es función, es servicio, es fuerza, y hasta profesión” (Pineda Castillo 1997, 68 - 69). 
aquello que las sociedades deben evitar de sus policías. Dicho de otra forma, las siguientes expresiones deben ser objeto de corrección, tanto al interior del mismo ente policía, y desde la sociedad y las instancias competentes para evitar tal sentido equivocado. Las connotaciones negativas son, entre otras: Abuso de poder, abuso de autoridad, arbitrariedad, corrupción, ilegalidad, ineficiencia, pérdida de legitimidad. También según describe la historiografía, policía degeneró en inquisición, terror, injusticia, autoritarismo y represión negativa?

\section{c) Sentido unívoco del ente policía}

Consiste en la orientación positiva del ente policía, según la cual, este se manifiesta en el mundo de la vida y de la realidad social como instrumento del poder político, pero, a favor de los principios democráticos, la convivencia pacífica, la dignidad humana y la vida como valor sagrado. Es claro que el ente policía no es un fin, sino un medio para el logro de dichos principios. De este modo, el sentido unívoco implica, asumir una posición ética, política y jurídica respecto a la naturaleza del ente policía, independientemente del contexto cultural desde el cual se conciba. En otras palabras, identificar el ente policía como instrumento benévolo del poder político, representa una propuesta consciente y crítica respecto al deber ser del fenómeno policial: es decir, prevalencia de la dignidad humana y de los derechos humanos universales garantes de la convivencia ${ }^{10}$. Si se pregunta cuál es la esencia y la razón de ser del ente policía, la respuesta es simple: la persona, la comunidad, el ser humano. Todas las demás cualidades de dicho ente deben, pues, estar supeditadas a este carácter intrínseco fundamental ${ }^{11}$.

En resumen, lo unívoco del ente se sintetiza en dos palabras: convivencia y legitimidad, con relación a una visión humanista en la cual prevalece el respeto y protección de la vida, la dignidad humana, y correlativamente, la cultura de la legalidad y la probidad del desarrollo de dicho ente policial. Es a partir de estos principios, que este estudio concibe el ente policía como el objeto de la ciencia policial. A continuación tanto los estudios sobre po-

9 "Represión" tiene también un sentido positivo en el mundo policial, por ejemplo, cuando las circunstancias delictivas exigen defender y proteger la vida mediante la "represión" del crimen.

10 Es posible que existan Estados no interesados en desarrollar un "ente policía" a favor del interés general de la sociedad, y que por el contrario, sus gobernantes de turno en su delirio de poder y protagonismo, decaigan en un sentido equívoco o equivocado.

11 En cuanto al sentido unívoco, según el General Londoño Cárdenas “Poder y régimen son esencias del ente policía (...) porque son la manera de ser de lo policial como totalidad, unidad y universalidad. Hacen que éste sea lo que es y no otro" (Londoño Cárdenas 2007, 88). 
licía como los trabajos explícitos sobre ciencia de policía, permiten entrever las diversas perspectivas desde las cuales se hace referencia indirecta y directa al mencionado objeto.

Ahora bien, la nueva ciencia policial es quizás la enmienda histórica respecto al sentido equívoco del ente policía ${ }^{12}$. Las desviaciones que haya tenido lo policial, tanto en el antiguo Estado absolutista, como en el moderno "Estado liberal", son ejemplo de aquello negativo que no debe ser y que se puede evitar, a través de un nuevo conocimiento científico comprometido con los principios y los valores de las sociedades democráticas respetuosas de la dignidad humana. Con esta afirmación se hace alusión a por lo menos tres ideas que es necesario aclarar, con el fin de comprender mejor la forma en que llegó a la América hispánica la denominada "ciencia de la policía" en su versión clásica o antigua, hasta convertirse en la "nueva ciencia policial". Estas ideas se refieren: uno, al origen de la ciencia de policía en el mundo español; dos, la conquista, colonia e independencia hispanoamericanas y la ciencia de policía; y tres, el cambio de la antigua a la nueva ciencia policial en Latinoamérica.

\section{Origen de la Ciencia de Policía en el Mundo ESPAÑOL Y LATINOAMERICANO}

Si bien la antigua ciencia de la policía tuvo su máximo desarrollo e Alemania del siglo XVIII con el cameralismo (Heinrich von Justi, Dithmar, Sonnelfels...), en Francia y España hubo otros desarrollos que luego se difundieron casi imperceptiblemente en la América hispánica. De los países europeos, es evidente la influencia directa de la obra de Delamare (Tratado de policía - 1705) y Turquet de Mayerne (Monarquía aristodemocrática 1617) en los autores españoles. Según Omar Guerrero, los principales autores y obras españolas de policía fueron: Francisco Romá y Rossell "Las señales de la felicidad de España y medios de hacerlas eficaces” (1768); Manuel Nicolás Marín "Discurso sobre la policía" (1792); Valentín de Foronda "Cartas sobre

12 Sentido equívoco del "ente policía" significa, aquella visión de lo policial en sentido negativo o peyorativo, como cuerpo represivo, autoritario, con abuso de poder o arbitrario, que comete actos fuera de la naturaleza legal que le había sido encargada. Por ejemplo, la policía secreta Nazi, o la policía Stalinista, o los atropellos de algunas dictaduras militares en Latinoamérica. En palabras más sencillas, los errores y horrores cometidos por algunos cuerpos policiales en ciertos lugares del mundo y bajo circunstancias históricas específicas, son cuestiones que no deben desviar el sentido de propender por un nuevo conocimiento científico policial a favor de los intereses generales de las sociedades contemporáneas, en el marco del Estado de derecho. 
la policía" (1792); Tomás de Valeriola "Idea general de policía: tratado de policía 13" (1798 - 1805); y Fermin Abella con el "Manual de policía urbana (1877). Y agrega el autor citado, que el primer libro español sobre policía no es peninsular sino novohispano: "Tratado de varios ramos de policía" escrito por el mexicano Hipólito Villaroel en 1787 (Guerrero, Omar 1986: 194).

De alguna manera, Alemania y Francia recibieron influencia recíproca sobre la ciencia de policía ${ }^{14}$, y este último país influye en España. Luego, la herencia de España y su ciencia policial en Hispanoamérica se revierte sobre el nuevo mundo y se diluye en los procesos de conquista y colonia casi como un eslabón perdido a través del tiempo.

\section{I CONQUISTA, COLONIA E INDEPENDENCIAS HISPANOAMERI- CANAS Y CIENCIA DE POLICÍA}

Según una crítica investigación sobre los orígenes del derecho administrativo colombiano realizada por Miguel Alejandro Malagón, “... la policía fue, en su primera acepción, el método utilizado para imponer a los aborígenes americanos el estilo de vida europeo. Esta forma de control se transformó a finales del siglo XVIII en lo que hoy conocemos -dice el autor- como civilización” (Malagón Pinzón, M. 2007: 301). Adicionalmente sostiene Malagón, que la relación entre policía y civilización en el siglo XIX fue una forma de implantar las instituciones de las misiones, las reducciones y los pueblos indios (2007: 301). En otras palabras, "vivir en policía" significó para el derecho administrativo colombiano el proceso de "civilización de indígenas", fenómeno atribuido a la Iglesia Católica, el cual pudo efectuarse también en otros países latinoamericanos. En este sentido, es posible afirmar que la llegada de la antigua ciencia de policía al mundo hispanoamericano se produjo -consciente o inconscientemente- por dos vías: una política y otra religiosa.

13 "Delamare fue traducido al castellano, pero sin darse el crédito. El plagio lo hizo según Jordana de Pozas el español Tomás Valeriola (Guerrero, Omar 1986: 202).

Por ejemplo, Von Justi menciona a Nicolás Delamare: “...ellos tienen (otros autores sobre policía), es verdad, libros que tienen su mérito, pero yo no hago caso sino del Tratado de policía de la Mare, que tiene cantidad de cosas útiles, excepto que le falta trabazón..." (Justi, Juan Enrique Gottlob (1784) 1996: 17).

14 Por ejemplo, Von Justi menciona a Nicolás Delamare: “...ellos tienen (otros autores sobre policía), es verdad, libros que tienen su mérito, pero yo no hago caso sino del Tratado de policía de la Mare, que tiene cantidad de cosas útiles, excepto que le falta trabazón...” (Justi, Juan Enrique Gottlob (1784) 1996: 17). 
En primer lugar, desde el punto de vista político, el truculento proceso de descubrimiento, conquista, colonia e independencia de la mayoría de los países latinoamericanos tuvo intensas orientaciones ideológicas. Al respecto, solamente cabe resaltar como referencia una de ellas: el pensamiento liberal, especialmente en el siglo XIX, dada su trascendencia para la evolución de la ciencia de policía en esta región. Para ello es oportuno citar a un eminente historiador quien sostiene, que "la historia del pensamiento político occidental ha girado en los dos últimos siglos ${ }^{15}$ alrededor de la concepción liberal del Estado. El liberalismo ha sido una de las fuerzas creadoras del Estado moderno, con todo lo que éste pueda tener de positivo o negativo desde el punto de vista social, y ya sea para superarlo, complementarlo o sustituirlo, en torno suyo se ha movido y se mueve todavía la teoría política de los pueblos europeos y americanos (...). La concepción liberal del Estado fue tan dominante en el siglo diecinueve XIX, que casi podríamos decir que fue la única existente..." (Jaramillo Uribe, Jaime 2001: Prefacio). Esta condición ideológica implica entonces, que la idea de policía (como civilización) inherente a la formación de los Estados criollos en Hispanoamérica, de alguna manera fue importada e instaurada durante el tránsito de la colonia hacia la independencia y la formación de la república. No es posible luego, comprender la naturaleza y la función de las instituciones latinoamericanas sin la fuerte influencia del liberalismo ${ }^{16}$. Sin embargo, se aclara que la antigua ciencia de la policía del Estado absolutista nada tenía que ver con el liberalismo, pero ésta corriente ideológica fue la que dio inicio a la "nueva ciencia policial" a partir de la segunda mitad del siglo XIX, entendida como ciencia de la administración pública (administración policial).

En segundo lugar, desde el punto de vista religioso, habría dos opciones: una, poner en cuestión la tesis de Malagón, esto es, negar que "el proceso de civilización de indígenas es derivado de la ciencia de la policía”, y otra, defenderla. Respeto a la primera postura, cabría preguntar hasta qué punto las comunidades religiosas de Dominicos, Franciscanos y Jesuítas que llega-

15 El citado autor redactó su Prefacio en el año de 1956, por tanto, los dos siglos precedentes a los que alude se cuentan desde la segunda mitad del siglo XVIII hasta la segunda mitad del siglo XX.

16 En el caso colombiano, con Antonio Nariño y Camilo Torres, directamente influenciados por las ideas de la ilustración francesa y por el pensamiento de los próceres de la emancipación de las colonias inglesas de América del Norte, la ilustración neogranadina adquiere una dimensión política. La publicación de los Derechos del hombre y su defensa por parte de Nariño y el Memorial de agravios de Camilo Torres en víspera de la independencia, representan dos piezas claves del pensamiento político ilustrado (Marquínez Argote, Germán 1988: 157 en La Filosofía en Colombia: Historia de las Ideas, Editorial el Búho, Bogotá - Colombia) 
ron de España al nuevo continente desde el siglo dieciséis XVI hasta el XIX, traían incorporadas la concepción de "policía" de los antiguos griegos y romanos, las ideas de policía de Delamare y Mayerne, o si conocían la doctrina de la ciencia de policía en la versión alemana. Y si tales comunidades hubieran tenido conocimiento de aquella ciencia de policía, ehubieran suplantado ésta ciencia por las enseñanzas religiosas ordenadas por el Papa a través de los Reyes Católicos?.

De otra parte, si se opta por la segunda postura, es muy probable que el proceso de evangelización, entendido como esencia espiritual de la colonización en la América india, implicara dentro de los principios del catolicismo, una serie de valores como: el respeto a la ley humana y Divina, la obediencia a la autoridad, la sumisión a un orden superior, y el respeto y el amor al prójimo, elementos fundamentales para el establecimiento de un orden en la tierra y hacer posible la convivencia y la coexistencia entre los humanos. Es decir, la idea de civilización está allí latente, y de este modo, "vivir en policía" sería equivalente a vivir civilizadamente con respeto a las leyes o reglas que define una comunidad para mantener un orden interno. También es necesario reconocer, que hubo destacadas figuras intelectuales de la Iglesia Católica que lucharon contra la esclavitud de los indios y negros en las tierras dominadas por España, y profesaron el humanismo cristiano, visión que inspiraba las ideas de justicia y paz. Y todo ese gran aporte se hizo desde el cultivo del conocimiento, bien haya sido primigeniamente desde la teología, el derecho y las ciencias naturales ${ }^{17}$.

Finalmente, quizás el lector se preguntará ¿qué relación tienen estos datos con la ciencia de policía en la región?. La respuesta es simple: la formación de los Estados en América Latina, el papel de la Iglesia y la permanente influencia del pensamiento europeo a través de la filosofía y el derecho, fueron los ejes de la administración pública de las nuevas naciones, saber éste que antes se denominaba "ciencia del Estado" o "ciencia de la policía”. En Co-

17 Es interesante y muy importante reconocer el mérito de las comunidades religiosas en cuanto al desarrollo del conocimiento científico y académico en la América hispánica durante los siglos XVI y XVII. La relación entre Iglesia y educación fue total, pues fueron las órdenes religiosas las primeras en fundar universidades siguiendo el modelo de Salamanca, universidad por aquella época en decadencia (siglo XVII). Para el caso colombiano, durante el siglo XVII funcionaron en Santa Fe dos universidades de derecho pontificio y real, la Tomista y la Javeriana, con otros colegios mayores como el del Rosario, San Bartolomé y San Buenaventura (Zabalza Iriarte, Joaquín 1988: 115, en "La Filosofía en Colombia: historia de las ideas" Editorial el Búho, Bogotá - Colombia). 
lombia, por ejemplo, la evolución del derecho con inspiración de la filosofía utilitarista de Jeremy Bentham fue determinante en la educación de inicios del siglo XIX y la posterior configuración de las constituciones políticas ${ }^{18}$.

\subsection{DE LA ANTIGUA A LA NUEVA CIENCIA POLICIAL EN LATINO-} AMÉRICA

Hasta el momento no se ha escrito oficialmente la historia de la ciencia de policía en América latina. Sólo se puede decir que aún existen vacíos teóricos e incluso conceptuales sobre su significado y sus implicaciones en la vida de las sociedades modernas de la región. No obstante a esta situación, es viable sostener las siguientes afirmaciones. En primer lugar, Latinoamérica más allá de su historia precolombina, es también producto y parte del mundo occidental. Esto quiere decir, que sus filosofías, tradiciones, instituciones y demás valores culturales constituyen un contexto diverso pero a la vez con ciertos rasgos comunes (idioma, religión, política...).

En segundo lugar, la formación de las repúblicas latinas trajo consigo de Europa las doctrinas del derecho administrativo y los conocimientos de la administración pública, los cuales son herencia de la antigua ciencia de la policía originaria del Estado absolutista, y son la transición hacia la nueva ciencia policial del Estado de derecho. Estas ideas generales son la apertura al siglo veinte $\mathrm{XX}$ y proyectan los desarrollos del anterior objeto de estudio.

En el caso latinoamericano, la nueva ciencia de policía es casi imperceptible, incluso desconocida. En cambio, la literatura que se difunde sobre policía (y la policía) de esta región, tiene que ver más con estudios en cuanto al comportamiento de los cuerpos policiales y su relación con las condiciones sociales y políticas contra la inseguridad y el conflicto. Con este énfasis, abundan estudios de caso, ensayos e investigaciones respecto a reforma policial, policía y sociedad, seguridad ciudadana, violencia y criminalidad, entre otros temas. Es decir, existe en cierta forma, un interés de diversos centros de investigación y una preocupación desde la comunidad académica, por investigar a la policía y los Estados a los cuales ellas pertenecen, pero no estudios expresamente sobre "ciencia policial en América latina”.

18 Este tema se aborda en la ciencia de policía en Colombia. 
Sin embargo, es importante mencionar algunos de los principales trabajos que tienen una relación indirecta con ella desde el punto de vista del contexto regional y las dinámicas de producción de conocimiento sobre el ente policía.

\section{Los Estudios sobre Policía en Latinoamérica}

Vale iniciar con una interesante compilación titulada "Policía y sociedad democrática" realizada por José María Rico y editada por Alianza de Madrid en 1983. Este mismo autor y Luis Salas publicaron en 1988 "Seguridad ciudadana y policía" (Editorial Tecnos, Madrid), estudios de corte sociológico-políticos, cuya línea y perspectiva se planteó posteriormente en un difundido análisis comparativo denominado "Seguridad ciudadana en América Latina”, publicado en el año 2003 por Siglo XXI México. Pero quizás uno de los trabajos de mayor crítica sobre el ente policía fue y ha sido "Justicia en la calle: ensayos sobre la policía en América Latina” 1996, compilado por Peter Waldmann y auspiciado por fundaciones alemanas y de la región.

Sin pretender simplificar los quince ensayos que componen esta última publicación, algunas ideas generales y críticas que se plantean allí son las siguientes: primero, la policía, entendida como institución del Estado, se ha convertido en objeto de interés investigativo desde el punto de vista político y científico (Waldmann); segundo, en casi ningún país latinoamericano se ha concretado, en rigor, la separación institucional entre el ejército y la policía (Aguila, Maldonado, Gamarra, Barrios), mezcla ésta de funciones que genera equívocos respecto a "enemigo externo", "enemigo social" y produce un policiamiento de los cuerpos militares y militarización de las policías; tercero, la debilidad estructural de los Estados latinoamericanos ha mostrado una tendencia hacia el abuso de poder (Gabaldón), y para ello, algunos gobiernos han utilizado sus instituciones policiales; cuarto, existe una subcultura en muchas policías de la región manifestada en arbitrariedades, discriminación, corrupción, y abuso de poder, motivos por los cuales, la policía goza de baja estima social (J. Maier, Riedmann, Mansilla, Huggins, Haritos-Fatouros, Mingardi); Quinto, comparativamente, la policía en Europa posee una función específica minuciosamente delimitada, como es, salvaguardar la seguridad y el orden públicos y perseguir a los delincuentes, y cuenta con los medios suficientes para esta labor, en cambio, la policía latinoamericana tiene tareas más difusas y no claramente demarcadas (M. Riekenberg). Y en sexto lugar, todo parece indicar, que las deficiencias jurídicas, éticas, organizativas, educativas y técnico-operativas, entre 
otras, de las instituciones policiales de América Latina, demandan un proceso de reforma de tipo estructural, aunque en grados e intensidades diferentes según cada país. Es de esta forma, que el conjunto de ensayos compilado en "Justicia en la calle" expresa su intención de aproximarse al "perfil real de la policía latinoamericana" (Waldmann, Peter 1996: 27).

Simultáneo al anterior estudio, hacia 1999 la Comisión Económica para América Latina y el Caribe CEPAL dio a conocer un trabajo titulado "Seguridad ciudadana y violencia en América Latina: diagnóstico y políticas en los años noventa", autoras Arriagada, Irma y Lorena Godoy. Aunque no figura como un análisis expreso sobre la policía, si aborda aspectos de su función y desempeño en la región. De otra parte, entre la diversidad de investigaciones sobre la policía en Latinoamérica se hallan las siguientes, cuyos títulos muestran una relativa tendencia "reformista" de las instituciones policiales:

En el año 2001 Hugo Frühling publica "La reforma policial y el proceso de democratización en América Latina” (Santiago de Chile, Centro de Estudios para el Desarrollo), luego en 2003 "Policía comunitaria y reforma policial en América latina: ¿cuál es el impacto?, en la Serie Documentos del Centro de Estudios en Seguridad Ciudadana, Instituto de Asuntos Públicos de la Universidad de Chile; y en 2006 "El desafío de la reforma policial en América Latina" Sin duda, uno de los debates centrales planteados por este autor es la cuestión sobre los modelos policiales y su dimensión socio-política.

Camacho Guizado, Alvaro (1993) "La reforma de la policía" (Revista Análisis Político No. 19 IEPRI, Colombia); Guerrero Peralta, Oscar (2003) "La policía en el Estado de derecho Latinoamericano: el caso Colombia"; Chevigny, Paul (2002) "Definiendo el rol de la policía en América latina”; Dominguez, Andrés (1998) "El Estado democrático de derecho y el poder de policía"; Goldstein, Herman (1998) "La nueva orientación policial: confrontando su complejidad"; Quintana, Juan Ramón (2003) "Policía y democracia en Bolivia: una política institucional pendiente"; Gómez, Juan Luis (2003) "Estado democrático y modelo policial", y con Richard Vogler (2003) "La policía en los Estados de derecho latinoamericanos"; Dammert, Lucía (2005) "Reforma policial en América Latina” (Revista Quórum, Universidad de Alcalá, España); Bailey, John y Dammert (2005) "Reforma policial y participación militar en el combate a la delincuencia: análisis y desafíos para América Latina" (Revista Fuerzas Armadas y Sociedad No. 19, Chile). Y con una extensa producción, Tudela Patricio ha publicado entre los años 2007 y 2008 "Sociedad y policía: 
desarrollo y retos de la función policial en las democracias latinoamericanas", y "Paradigmas policiales orientados a la comunidad en América Latina: entre realismo mágico y gestión de conocimiento”.

\section{Estudios Explícitos sobre Ciencia de Policía En América Latina}

La perspectiva latinoamericana de la ciencia policial no es una expectativa intelectual de exclusividad académica. Por el contrario, no han sido solamente las instituciones policiales a través de sus academias o escuelas de formación las interesadas en el desarrollo de la ciencia de policía, sino también algunos investigadores universitarios externos a ellas, pero identificados con la importancia de su aparición.

A diferencia de todas las demás ciencias sociales, la ciencia de policía es quizás aquella que debe explicitar abiertamente su concepción ética sobre la vida y el tipo de mundo que pretende en sus fines últimos. A diferencia de otros científicos sociales que deben disimular su inclinación ideológica, o parecer "neutros" u "objetivos" ante ciertos fenómenos deplorables de la realidad humana, la personalidad del científico policial, sin despreciar éstos criterios epistemológicos, orienta con nitidez su rumbo metodológico y afina coherentemente sus estrategias de conocimiento, porque sabe bien hacia dónde va, cuál es el fin y el sentido de su trabajo sistemático: contribuir a la convivencia.

Es difícil, luego, negar cierto espíritu humanista y futurista que inspira el apetito cognitivo y la búsqueda de ciencia en el ámbito policial. La motivación institucional de vislumbrar y desarrollar sistemas de pensamiento que faciliten la implementación de formas de hacer mejor las cosas, pero sobre todo, de hacerlas no sólo con método, sino con razón, sentido, anticipación y prospectiva, incitan la conciencia plural de esfuerzos para el caso de esta región del planeta y sus relaciones con el resto del mundo.

La anterior insinuación axiológica permite entonces, comprender por qué en países como Argentina, Colombia, México y Perú, la llamada ciencia de policía aparece como interés explícito y como expresión consciente sobre la trascendencia que la tríada conocimiento, policía y sociedad implica para el aumento de la calidad de vida y el desarrollo humano. 


\section{I LA CIENCIA DE POLICÍA EN ARGENTINA. ENRIQUE FENTANES}

Enrique Fentanes representa la labor pionera de la ciencia de policía en Suramérica. Su importancia radica, entre otras razones, en ser el primer autor latinoamericano que se atreve a escribir y publicar en 1972 un "Tratado de ciencia de la policía ${ }^{19 ”}$. Desafortunadamente, sólo dejó como legado el Tomo I, titulado "Introducción Dogmática General”, Primera Parte. Póstumamente en 1979 fue publicado su "Compendio de Ciencia de la Policía", como homenaje a su obra inconclusa, la cual es un precedente significativo sobre una interesante visión latinoamericana de la nueva ciencia policial en el siglo veinte. Es más, la obra de Fentanes aún es virginal, pues hasta el momento no se registran estudios sobre la densidad de sus planteamientos, a excepción de su seguidor colombiano el general Fabio Arturo Londoño Cárdenas, quien en sus libros refleja la juiciosa lectura del autor ${ }^{20}$.

Sin pretender una síntesis de la obra de Fentanes, a continuación se extraen y describen su concepto de ciencia de la policía, su objeto y método, y algunas implicaciones teórico - prácticas de dichos planteamientos.

\section{a) Concepto de ciencia de la policía según Fentanes}

Para este autor "la Ciencia de la policía tiene por objeto el estudio sistemático y metódico de la Policía como Institución y como estructura. En términos programáticos, se propone el conocimiento de la esencia institucional y estructural de la Policía, su origen, evolución, componentes funcionales y orgánicos, relaciones y fines ${ }^{21}$ " (Fentanes 1972: 15 - 16). Para concebir y sustentar el concepto de ciencia, el autor bebe de fuentes clásicas como Aristóteles, Kant "Principios metafísicos de la ciencia natural", Herbert Spencer, Eduard Spranger, Georges Bordeau, Wundt y Dilthey, entre las principales. De modo especial, para fundamentar la naturaleza "institucional" de la policía, Fentanes aplica la teoría de la institución de Maurice Hauriou ${ }^{22}$. Sin más complicaciones ni adentrarse en debates epistemológicos, Fentanes adopta

19 Fentanes, Enrique (1972) “Tratado de ciencia de la policía” Tomo I Introducción Dogmática General. Editorial Policial - Policía Federal Argentina, Buenos Aires.

20 En la segunda parte de este trabajo "La ciencia de policía en Colombia" se amplía la influencia de Fentanes en la obra de Londoño Cárdenas.

21 Se transcribe fielmente al texto original, en el cual las letras iniciales de Ciencia y Policía aparecen en mayúscula.

22 Hauriou, Maurice (1929) “Compendio de derecho constitucional” - Paris. 
un concepto sencillo de ciencia, como aquella noción clásica según la cual, ciencia es aquel conocimiento que implica un "sistema", posee un "objeto" definido, y cuenta con un "método" para el logro de sus fines.

Es en este sentido que al plantear los principios epistemológicos afirma: "La denominación de Ciencia que hemos dado a nuestra disciplina, implica la afirmación de que el estudio de la Policía, tal como le encaramos en este Tratado, asume la calidad de conocimiento científico. Este se distingue, ante todo, por ser un conocimiento sistemático. La ciencia es un sistema de conocimientos. Nuestro estudio cumple, por consiguiente, la primera condición del saber científico: el sistema. Pero ello no basta. Pueden estudiarse muchas cosas sistemáticamente, sin que el que-hacer asuma categoría científica" (Fentanes 1972: 13 -14). Entre tanto, las características que le otorga a la ciencia de la policía son: "ciencia unitaria" en el sentido que su objeto -la Policía- es universal, y de concepción "holológica", porque dicho objeto es enfocado en una totalidad. "De tal modo que concurren a integrarla, contribuciones de disciplinas jurídicas, políticas, históricas, psicológicas sociales, filosóficas, en cuanto sea necesario para investigar y exponer los distintos componentes y elementos estructurales de un objeto tan complejo" (Fentanes 1972: 17).

No obstante, más adelante adiciona la siguiente afirmación: "La Ciencia de la Policía no abarca todas las disciplinas y técnicas policiales. Es unitaria por su objeto y en cuanto a su objeto. Pero no incluye en su seno todas las materias en las cuales aparece la Policía actuando en dominios generales o específicos del Derecho o de la Técnica. Esas materias, sin embargo, no son plenamente autonómicas. No pueden trabajar con concepciones propias acerca de la Institución policial, su naturaleza, función y relaciones. Tampoco con categorías, conceptos y principios de doméstica construcción, que por lo común, resultan ambiguos, insuficientes, dispares y muchas veces antagónicos" (Fentanes 1972: 21). A lo que teme Fentanes, en cierto modo, es a la arbitrariedad que pueda tener cada disciplina de querer interpretar a su modo y parcialmente qué es la policía, cuál es su esencia, etc. En particular, advierte sobre el riesgo que el derecho positivo (o el positivismo jurídico) muy afín al conocimiento científico policial desde su autonomía disciplinaria absorba un objeto tan complejo, un objeto de la cultura como la Policía.

\section{b) El objeto de la ciencia de policía}

Como sostiene Fentanes, el objeto de la ciencia de policía es "la Po- 
licía como Institución y como estructura”. Y agrega: "La Policía es un objeto que existe en el mundo de la Cultura ${ }^{23}$. Cultura es todo lo creado o cultivado por el hombre según fines valorados. La disciplina destinada a estudiar la Policía es una ciencia de la cultura. Por ende, es una ciencia de hechos y normas de la cultura, histórica, finalista y valorativa” (Fentanes 1972: 16). Páginas adelante reitera y enfatiza la naturaleza y objeto de la ciencia de policía: "Una disciplina de esta naturaleza es una ciencia de hechos y normas de la cultura, histórica, finalista y valorativa. Su objeto es un objeto cultural, y, por ende, real, histórico y axiológico" (Fentanes 1972: 46). Esta concepción ontológica de la policía (su ser, esencia y existencia) conlleva un alto grado de complejidad para su análisis, y la necesidad de propender por un método coherente a su naturaleza. Esta es la siguiente idea.

\section{c) El método cultural de la ciencia de policía: teoría de los análisis}

El conocimiento científico se caracteriza por su objeto y por su método, y este último está determinado por el primero, dice Fentanes. Por "método" entiende "el conjunto de reglas para el proceso cognoscitivo, el cual debe atenerse al objeto de la ciencia ${ }^{24}$. Cuando el objeto es complejo, como nuestro caso -dice- resultará forzosamente necesaria la aplicación de un complejo metodológico. Deberemos utilizar todos aquellos métodos que se adecúen a los distintos puntos de mira hacia el objeto. El objeto determina, pues, los métodos. De conformidad con este principio, y como el primer punto de mira, en esta parte de la Dogmática, el método enfoca a la Policía como Institución, es decir, el punto de partida de la metodología es el contenido del concepto de Institución" (Fentanes 1972: 39 - 40). Sin embargo, para este autor, una ciencia de la cultura es una ciencia de hechos y normas de la cultura, histórica, finalista y valorativa. En consecuencia, forzosamente sus métodos deben satisfacer las exigencias cognoscitivas en todos y cada uno de esos enfoques del contenido.

Y dado que la policía es un objeto que existe en el mundo de la cultura, el método de la ciencia policial será un método cultural. Al respecto, Fentanes muy sintonizado con las cuestiones epistemológicas de la época adhiere la tesis según la cual el pensamiento científico contemporáneo sostiene que "el pluralismo de métodos es norma aceptada para todas aquellas ciencias

23 Fentanes alude a la clasificación de las ciencias hecha por Dilthey "ciencias del espíritu y ciencias de la naturaleza"; también se refiere a Wundt en cuanto a la denominación "ciencias sociales, ciencias humanas o ciencias del hombre”, pero sobre todo, acoge la noción del filósofo alemán Ernest Cassirer "Las ciencias de la cultura" (F.C.E. México-Buenos Aires, 1951).

24 Fentanes acude a Georges Bordeau (1964) “Método de la ciencia política” Editorial Depalma, Buenos Aires. 
cuyo objeto deba ser enfocado desde distintos puntos de vista (...) y este en síntesis, es el método cultural (...). El método cultural, -dice Fentanes- como cualquier otro, implica un proceso cognoscitivo, es decir, una serie progresiva de procedimientos y técnicas, que pueden ordenarse en etapas o fases. En un orden aparentemente lógico, la primera fase sería la investigación, o sea, la observación y descripción de los hechos y normas que se refieren al contenido de la disciplina. Sin embargo, la investigación no puede realizarse sino dentro de un cuadro sistemático, categorial y conceptual. No se puede buscar sin saber lo que se busca y para qué se busca. Es necesaria entonces una guía, una orientación (Fentanes 1972: 44 - 45).

Finalmente para explicar las fases del proceso cognoscitivo del método cultural, Fentanes expone la teoría de los análisis o teoría de las fases analíticas. $\mathrm{Al}$ respecto sostiene: "El método cultural propio de una ciencia de la cultura versa, a nuestro parecer, sobre las siguientes fases:

- Análisis de la realidad cultural

- Análisis histórico

- Análisis normativo (o específicamente jurídico, sin olvidar que éste es una especie de lo normativo)

- Análisis finalista (en el orden a los fines propios de la ciencia)

- Análisis valorativo (o axiológico en el orden pleno de los valores)

Aclara también que adopta el término "análisis" para significar cada fase, que a veces conforma, a su vez, un complejo de métodos específicos, técnicas y procedimientos. Es decir, el método cultural de la ciencia de policía implica dentro de sí, otros métodos, según cada tipo de análisis, y no de forma lineal o no necesariamente en el orden que se plantea anteriormente. Y es un método "sincrético", esto es, un método que concilia diferentes ordenes (cultural, histórico, jurídico, axiológico...) para lograr el análisis científico del objeto.

\subsection{LA CIENCIA POLICIAL EN COLOMBIA}

\section{A) La Ciencia de Policía desde el Derecho de Policía. Fabio Artu- ro Londoño Cárdenas}

El General Londoño, nacido en Medellín en 1929, representa la labor pionera de la ciencia policial y del derecho de policía en Colombia. 
Como se mencionó páginas atrás, Londoño exalta la obra de dos eminentes jurisconsultos, fuentes de su inspiración: Miguel Lleras Pizarro autor de "Derecho de policía: ensayo de una teoría general" (1943), y Roberto Pineda Castillo autor de "La policía: doctrina, historia y legislación" (1950). Y con la obra de Enrique Fentanes, más su conocimiento de los clásicos de la filosofía, la sociología, el derecho y otras disciplinas humanísticas, el citado logra arar el terreno y sembrar una serie de ideas fecundas respecto a la naturaleza y futuro del ente policía, la concepción del Estado y la disciplina cívica que requiere una sociedad para su desarrollo material y espiritual.

Si bien la literatura de Londoño es de tono radical y de postura firme, la filosofía humanista y cristiana (Escolástica) son el telón de fondo orientador de su pensamiento, sin abandonar la crítica y la proyección sobre el porvenir.

\section{- Naturaleza e importancia del derecho de policía}

Su punto de partida es indudablemente el derecho de policía y su importancia jurídico social ${ }^{25}$. Como él mismo afirma, "A pesar de ser el concepto de policía de viejo conocimiento, como ciencia y como manera de conducta, como ciencia jurídica apenas se viene a presentar, curiosa o afortunadamente, en Colombia en la década del 40, o más exactamente en el año 1943 cuando Lleras Pizarro publicó su tesis "Derecho de policía" en la Universidad Nacional de Colombia (Londoño 2006: 23). Es decir, la ciencia de policía nace en este país en dicho año desde el punto de vista jurídico. Y agrega: “...hasta esa fecha no existía un texto en el cual se estudiara o se expusiera la policía como ciencia y como derecho autónomo que es". En resumidas cuentas, a partir de aquel entonces, el ente policía se convertía en una de las más importantes manifestaciones del Derecho público moderno.

Pero ¿qué es el derecho de policía? Desde éste, la función policial "ha tenido y mantendrá una gran relevancia porque sin ella es imposible que una sociedad cualquiera coexista pacíficamente. En un Estado de derecho ha de ejercerse por el Ejecutivo, en muy estrecha cooperación y armonía con el ju-

25 Según Olivar Bonilla, Leonel (1995: 13) el "Derecho de policía se define como el conjunto de normas establecidas por el Estado para la reglamentación de las libertades públicas, con el fin de garantizar la tranquilidad, la seguridad, la moralidad y la salubridad públicas". Otro concepto más amplio y reciente sobre derecho de policía sostiene: "Es una disciplina de las ciencias jurídicas que tiene como objeto garantizar derechos y libertades, a través de la atención de motivos de policía, mediante la selección de medios que permitan aplicar medidas y procedimientos, para el cumplimiento de su fin: la convivencia. (Trujillo Mahecha, Juan Carlos y Vera Moreno, Raúl (2010) Comentarios sobre la obra Derecho de policía de Miguel Lleras Pizarro. 
dicial, porque la investigación y en especial la acción penal o punitiva por los ilícitos que cometa una persona, solamente esta rama puede realizarla con amplitud, y la acción por las faltas de las personas que corresponde a la policía, se ejerce únicamente por tal autoridad" (Londoño 2006: 29). En otras palabras, sin la función policial, o en su ausencia, el caos y la impunidad sobrevienen.

Entre tanto, una parte del ente policía, el cuerpo institución, ha de tener como eje estructural de su conocimiento científico, la disciplina del derecho policiaco para enfrentar los problemas sociales: la importancia política, ético-deontológica y social de dicho saber depende del cumplimiento de su fin, como es la convivencia.

\section{- El objeto y fin de la ciencia jurídico policial}

La ciencia de policía es una ciencia jurídica y es una ciencia social. Para Londoño es absolutamente claro que el denominado "orden público" ya no ha de tener cabida como fin de la policía, y en su lugar, la convivencia es y será el auténtico destino. Entre las razones expuestas, sostiene que “26...el orden público es un término ambiguo y anacrónico que genera dudas, confunde roles y desconoce la autoridad de policía, pues este concepto involucra la defensa y seguridad nacional, condición ligada a la soberanía del Estado. Es decir, es un concepto político que se refiere a una forma de organización social soberana y coercitiva, formada por un conjunto de instituciones sociopolíticas que tienen el poder de regular la vida sobre un territorio determinado -que deriva en el uso de la fuerza para su defensa, propia de los cuerpos militares, quienes por la amplitud del concepto, se imponen indirectamente a los jefes de policía amparados en su capacidad de fuerza; por tanto -continúa Londoño- al involucrarse la defensa del Estado se desconoce lo que es propio al derecho de policía: el ser humano como verdadera razón del existir del Estado, si no es para servir a la sociedad entonces qué razón de ser tiene dicho Estado, por lo que es erróneo involucrar en el fin del derecho de policía la defensa del Estado lo que se da al utilizar el concepto de orden público; que además aleja al ciudadano de participar en el desarrollo de la convivencia, ya que lo público es asociado por la comunidad como propio y casi de exclusiva responsabilidad del Estado, desentrañándolo de las personas; la fuerza en el derecho de policía es y será el último medio, como sí ocurre en la defensa de

26 El siguiente es un comentario de Londoño Cárdenas a la edición reimpresa y actualizada de Lleras Pizarro "Derecho de policía: ensayo de una teoría general” 2009. 
la soberanía del Estado" (Lleras Pizarro, Miguel 2009: 39 - 40). Ampliado y en cierto modo superado este concepto de su maestro, Londoño reafirma que no se trata de cualquier convivencia, sino de la convivencia democrática de la sociedad.

Entendido el anterior fin, el reto y la tarea de la ciencia jurídico policial es estudiar a fondo su objeto: "la libertad del hombre con su dignidad y todos los derechos que garantizan las declaraciones universales y la Constitución Nacional; (y dentro de este objeto de estudio) el significado y contenido del poder de policía y del régimen de policía; los motivos, los medios, las medidas y las funciones policiales; la fuente del derecho de policía, su origen y desarrollo, sus límites, y el control del mismo ente policial y su futuro" (Londoño 2006: 22).

De lo antes enunciado se puede inferir lo siguiente. De una parte, que la ciencia de policía es una ciencia jurídico social, y sobre todo sociológica, al ser para ella determinante el conjunto de las relaciones entre los individuos que componen una sociedad, más aún cuando sus libertades y dignidad están en juego. De otra, el derecho de policía, base de la ciencia policial para Londoño, sustenta el rasgo político de la naturaleza del ente policía: uno de sus componentes, la policía como cuerpo, es la primera institución política de la sociedad, así, la trascendencia de esta concepción

\section{- El concepto de ciencia de policía y su objeto}

Londoño comparte el concepto de ciencia policial de Fentanes que dice: la "ciencia de la policía tiene por objeto el estudio sistemático y metódico de la policía como institución y como estructura" (Fentanes citado en Londoño, C. 2007, 105). Pero este último autor amplía este concepto: "Para nosotros la ciencia policíaca es, entonces, el estudio sistemático y metódico del ente policía, sus causas, evolución y señalamiento de sus principios" (Londoño C 2007: 105). En estos términos, uno de los grandes aportes del General Fabio Arturo es incluir el concepto de "ente policía", el cual concibe del siguiente modo. En primer lugar, toma esta noción de la metafísica, y dice: "La noción del ente no es simple, está compuesta de un sujeto y un acto en que intervienen dos elementos: el ser de esa cosa (esencia) y su realidad (existencia)" (Londoño 2007: 84). En segundo lugar, al acuñar las dos palabras -ente-policía-, el autor sugiere los siguientes criterios para estudiar este objeto: filosofía, método o sistematización, visión histórica, estudio crítico y multidimensional. 


\section{- Algunos criterios para estudiar el ente policía}

Una filosofía policial: el "ente policía" como objeto de la ciencia policial, debe ser entendido como "universalidad, totalidad y unicidad", para identificar sus características, categorías, fenómenos y propiedades particulares, entre otros aspectos. Es decir, este criterio resalta la importancia de reflexionar filosóficamente sobre la naturaleza de aquello que se denomina "policía", con suficiente amplitud y crítica, a partir de bases tanto físicas (el fenómeno policial, cuerpo-institución...), como "bases metafísicas: poder de policía, régimen de policía (...)” (Londoño Cárdenas 2007, 87).

Estudio sistemático y metódico: la ciencia de policía implica un abordaje ordenado del fenómeno policial, para cuya tarea se debe construir o aplicar un método diferente al de otras ciencias, pero con ayuda de ellas o sin desconocer sus valiosos aportes, relaciones e interdependencias disciplinarias de conocimiento. En consecuencia, "el estudio de la cuestión policial conforma un problema que comprende un objeto variado y múltiple que exige igualmente una metodología compleja, o sea, que se necesita considerar los diferentes caminos que conducen al objeto policial, y, luego, la consecución del mismo determina los métodos que se deben utilizar" (Londoño Cárdenas 2007, 115).

Visión histórica: para obtener una comprensión clara de lo que fue, es y será el fenómeno policial o ente policía, es indudable la necesidad de rastrear en la historia aquello que lo produjo (sus causas), cómo han sido las transformaciones de dicho ente policial (su evolución), y cuáles paradigmas de pensamiento o formas de racionalidad han determinado sus principios: desde la noción griega de orden y virtud, el arte moderno de gobernar o ciencia del Estado, hasta la criminología y el derecho de policía en el siglo XX, por ejemplo.

Estudio crítico y multidimensional: en sintonía a lo anterior, Londoño comparte el concepto de su colega y amigo, el General Miguel Antonio Gómez Padilla: "la ciencia policial es el estudio sistemático, ordenado y crítico del ente policía, en su contexto histórico, cultural, sociológico, político, económico y filosófico, y en su dimensión universal y local" (Gómez Padilla 2008). Cabe resaltar luego, el complemento multidimensional e interdisciplinario que demanda el estudio de la ciencia policial, pero sobre todo, la exigencia de una actitud crítica respecto al "ente policía". 


\section{- Razones de conciencia crítica}

La actitud crítica sobre el objeto de la ciencia policial supone como mínimo tres razones: primero, diferenciar entre el "deber ser" y "el ser" de la policía a través de la historia, o diferenciar entre lo que idealmente se aspira que ella sea, y aquello que en otro tiempo y lugar fue y no es lo ideal, es decir, aprender de los aciertos y de los errores históricos; segundo, tomar conciencia de la identificación ideológica desde la cual se estudia la ciencia policial, y hacer autocrítica del propio sesgo para propender por la objetividad y el carácter universal que exige la labor científica en su sentido clásico. Y tercero, reconocer que la ciencia policial no es la construcción de un conocimiento ingenuo, sino, por el contrario, que se constituye como un saber intencionalmente explícito e inscrito en un contexto particular que determina los principios, valores, virtudes y prácticas de una institucionalidad con fines socialmente legítimos o aceptados democráticamente.

\section{- Trascendencia del lenguaje científico policial}

Para Londoño la ciencia de policía debe desarrollar -como toda ciencia- su propio lenguaje. Ceder en las palabras es ceder en los hechos, y si los cuerpos policiales pretenden ostentar profesionalismo de su función, deben así mismo, edificar y preservar el uso celoso de cada término, categoría y expresión. De modo sencillo, el tránsito desde el conocimiento policial precientífico hacia el conocimiento científico policial (doctrina) es, solamente posible, si se estructura mediante el rigor semántico y lingüístico del lenguaje técnico capaz de articular coherentemente la realidad con aquello que se dice de ella misma. Y para el autor comentado, estos aspectos cobran total trascendencia en el ámbito del derecho de policía.

Así como Fentanes se inspira en el aforismo "la ciencia es un lenguaje bien hecho" del filósofo francés Étienne de Condillac (1715-80), Londoño retoma de su colega argentino "El análisis terminológico y conceptual" de la ciencia policial, correspondiente al método cultural y la teoría de los análisis. Los dos (Londoño y Fentanes) son conscientes de la trascendencia del lenguaje a la hora de hacer ciencia, pues de ella depende la generación de doctrina, y ésta a su vez, se supone como el lenguaje unívoco del cuerpo institución y del ente policía en general. La doctrina de la ciencia policial será entonces el lenguaje con estatus de cientificidad, o dicho de otro modo, existe ciencia policial cuando existe un lenguaje adecuado o de naturaleza científica. 


\section{- Crítica al uso de ciertas expresiones}

Londoño hace una sensible crítica al uso de ciertas voces utilizadas en el ámbito policial, muchas de ellas "importadas que han fijado conceptos notablemente erróneos y dañinos porque, como verdaderas taras, -sostienese han metido en la mente de sus integrantes y han tergiversado o modificado a fondo principios del pensamiento esencial a la ciencia y función policial. Ejemplos que desorientan el conocimiento y el ser policial son: "tropas", "operativos", "guerra", "enemigo", así como las voces "empresa", "cliente”, "gerente", "evidencias", etc. Igualmente - prosigue- las dicciones contradictorias: "policía judicial" y "policía de control"; o las pleonásticas e importadas sin la adecuación debida como: "policía comunitaria", "policía de proximidad", "seguridad ciudadana”, y otros adefesios por el estilo" (Londoño 2007: 149). Pero no se trata de una simple crítica a la emergencia de expresiones coyunturales, o de épocas "de moda", sino más bien, es la advertencia y la exhortación que hace Londoño para que el ente policía no esté al vaivén inconsciente de intereses ajenos o particulares, y no sea desvirtuada su naturaleza civil, ni tergiversados sus principios, ni desviado de su fin primordial.

En sintonía con Fentanes, "no se pretende reducir tal quehacer (científico policial) a una sola preceptiva terminológica, sino destacar la importancia que asume, en toda disciplina, la utilización de términos claros, inequívocos y que correspondan exactamente al contenido significado. Esta problemática -afirma Fentanes- subyace en todo producto del pensamiento, cualquiera sea su índole. Puede tolerarse, aunque no justificarse, la ingenuidad y desaprensión con que los profanos manejan los conceptos en la vida diaria, social, literaria, política. Pero, ya en el plano científico, es imperdonable que, como suele verse aún en tratados y ensayos de alto vuelo, el autor entre en materia con un instrumento conceptual ambiguo, o establecido sin exponer su fundamentación, o asentado en criterios personales y arbitrarios. Podría decirse, sin temor a exagerar, -reafirma Fentanes- que la desorientación y la crisis reinantes en distintas esferas del pensamiento moderno obedecen, en gran parte, al descuido en la conceptualización o a los excesos del conceptualismo (Fentanes 1972: 141 - 142, citado por Londoño, 2007).

En definitiva, la nueva ciencia policial desde la perspectiva del derecho de policía, plantea aquel problema central de toda filosofía según Ludwig Wittgenstein (1889 - 1951): la concepción del lenguaje lógicamente perfecto o ideal, porque sin crítica al lenguaje no hay crítica ni construcción de nuevo pensamiento. 


\section{B) La ciencia de Policía, Profesionalización y Cultura Policiales. Miguel Antonio Gómez Padilla ${ }^{27}$}

\section{- Ciencia y ente policiales}

Para el General y exdirector de la Policía Nacional de Colombia, "existe una ciencia autónoma llamada Ciencia de Policía, que ha evolucionado a partir de la experiencia y la investigación científica, integrada por la filosofía, el derecho, la sociología, la antropología y la psicología policiales, entre otras" (Gómez Padilla, M. A. 2009: 3). De similar modo al General Londoño, Gómez reconoce el carácter interdisciplinario de la ciencia policial, respecto a lo cual sostiene: "Es evidente que la ciencia policial requiere auxiliarse de otros campos del conocimiento. El riesgo está -afirma- , y, es lo que al parecer sucede, que lo aparentemente complementario se convierte en principal. De allí los errores que desdibujan la imagen del funcionario policial. -Y enfatiza- ... me aventuro a definir la ciencia policial como el estudio sistemático, ordenado y crítico del ente policía en su contexto histórico cultural, sociológico, político, económico y filosófico en su dimensión universal y local" (Ibídem: 4).

Adicionalmente, un aspecto interesante planteado por el General Gómez Padilla consiste en su concepción sobre el ente policía, según la cual, aquel lo integran tres tipos de actores estatales: quienes regulan el ejercicio de las libertades y derechos (poder de policía); quienes administran la función de policía; y quienes ejecutan la función de policía. Se infiere que al primero corresponden instancias como el Congreso de la República, las Asambleas departamentales, y los Concejos municipales (y excepcionalmente el Presidente); al segundo las instancias del poder político-administrativo como el presidente, gobernadores, y alcaldes; y al tercero, los cuerpos de policía (Ver Figura 1). Desde este punto de vista, es notable el énfasis jurídico-político del objeto de la ciencia policial afín a la línea de su coetáneo el General Londoño Cárdenas. En cuanto al fin de esta ciencia, Gómez sostiene que ella se encarga de asegurar el ejercicio de las libertades y derechos para lograr la convivencia ${ }^{28}$. Es importante anotar, que el poder de policía lo detentan especialmente quienes tienen la facultad de expedir leyes y/o normas que regulan las libertades y derechos. Las demás son funciones (administrar, ejecutar) del desarrollo legal de dicho poder (régimen de policía) ${ }^{29}$.

27 Estas nociones son tomadas de entrevistas con el General Miguel Antonio Gómez Padilla, de algunos de sus manuscritos y la publicación de su texto "Oraciones Policiales" (2009).

28 El fin de la ciencia de policía según el General Gómez Padilla es consecuente con lo estipulado en el Artículo 218 de la Constitución Política de Colombia de 1991.

29 Según Gómez Padilla el “poder de policía” se concentra en quienes “regulan” el ejercicio de las libertades 
Figura 1: Estructura del ente policía

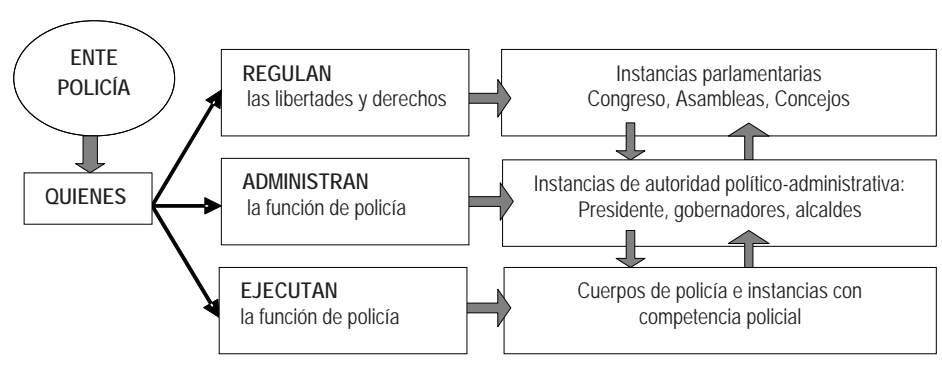

Fuente: elaboración a partir de Gómez Padilla CEPEP (2009)

\section{- Educación y profesionalización policiales}

Para el General Gómez "corresponde al sistema docente policial a través de sus escuelas interiorizar en los futuros policías la cultura policial y transmitirle el saber de su ciencia en su contexto universal y local. Es mediante el currículo, -dice- como formamos profesionales en policía”. -Y alude a Emile Durkheim: "La educación es la acción ejercida por las generaciones adultas sobre las que aún no se encuentran preparadas para la vida social (nuevos policías); y tiene por objeto crear y desarrollar en las personas una serie de estados físicos, intelectuales y morales, reclamados por la sociedad política en su conjunto y por el medio particular en que se desenvuelve" (el cuerpo institución policía)".

y derechos (Congreso, Asambleas, Concejos) y eventualmente la Rama Ejecutiva. No obstante, Libardo Rodríguez explica este concepto a partir de las funciones que le competen al Presidente de la República: “Conservar el orden público: la vida de todos los Estados está sujeta a la existencia de unas condiciones mínimas que le permitan a la organización jurídica estatal ofrecer a sus miembros la posibilidad de vivir correcta y normalmente en comunidad. Es el llamado orden público. Esas condiciones mínimas tradicionalmente se ha dicho que están constituidas por la tranquilidad, seguridad y salubridad que deben existir en toda comunidad para su buena marcha. De manera que el Estado debe tomar las medidas necesarias para evitar que se presenten fallas en esas condiciones o, por lo menos, para impedir que las fallas se prolonguen cuando ya se han presentado. Esta facultad se conoce jurídicamente con el nombre de poder de policía. A este respecto, si bien ese poder de policía está dado a diferentes autoridades, es el presidente de la república el principal encargado de utilizarlo. Así, la Constitución Política de Colombia le confiere ese poder en dos grados diferentes. Por una parte, un poder de policía normal u ordinario consagrado en el numeral 4 del Artículo 189, según el cual corresponde al presidente "conservar en todo el territorio el orden público y restablecerlo donde fuere turbado". Por otra parte, un poder de policía extraordinario consagrado en los artículos 212 a 215 de la Constitución, para los casos de guerra exterior, conmoción interior y estado de emergencia" (Rodríguez R. Libardo, 2008: 67) "Estructura del poder público en Colombia”. Décima edición, Editorial Temis, Bogotá - Colombia. Ver también Torres Rico, Remberto (2008). Finalmente vale anotar, que los Generales Gómez Padilla y Londoño Cárdenas consideran que uno de los grandes cambios paradigmáticos de la Constitución de 1991 fue pasar del concepto de "orden público" al de "convivencia", dadas las connotaciones políticas y sociales que implica el ejercicio de dicho poder de policía. 
Gómez tiene la convicción que la educación y la profesionalización de los cuerpos policiales son condiciones esenciales para edificar tanto la cultura policial como la ciencia de policía, pero especialmente, enfatiza en el carácter democrático y democratizador de las Escuelas de formación policial: “...las Escuelas (...) deben funcionar como auténticas sociedades democráticas y cumplir una función democratizadora. Los alumnos durante su proceso de formativo, irán construyendo las virtudes y valores indispensables para el recto ejercicio de la función policial y se irán adornando de todas las cualidades que la sociedad espera y exige de ellos; -y continúa- recordemos a Platón: el fin de la educación es el desarrollo completo y armonioso del cuerpo y el alma. Los institutos docentes policiales deben ser unos extraordinarios laboratorios en donde tenga aplicación el ejercicio de las libertades y derechos que más tarde ellos estarán obligados a tutelar, es decir, que en ellas se debe vivir la civilidad. De allí lo delicado y complejo de esta labor; no hay lugar para la improvisación (...)" (Gómez Padilla, M. A, 2009: 153). Es evidente que para este autor, sólo se le puede exigir al hombre o mujer policía aquello que se le ha enseñado y ha vivido durante su proceso de formación, como lo es, una educación democrática y democratizadora replicable fuera de las aulas, en la sociedad.

\section{- Cultura policial ${ }^{30}$}

Un concepto relacionado con la ciencia de policía para Gómez Padilla es el de "cultura policial". Para explicarlo, retoma nociones clásicas sobre qué se entiende por cultura ${ }^{31}$ y luego las relaciona con una definición de policía. En primer lugar, asocia la idea de "cultura" con el de "conciencia histórica y memoria", y cita a H. Gianini: "Una sociedad sin conciencia histórica- sin memoria- es un hacinamiento de soledades que solo se disputan un espacio, por cuanto no les pertenece tiempo común alguno. -Y continúa- El tiempo y el olvido producen disgregación de lo sucedido; de allí lo indispensable de la memoria (...)". Luego, sintetiza de varios autores las siguientes ideas: "cultura es todo aquello que el hombre crea y recrea pero igualmente es el conjunto de rasgos distintivos, espirituales y materiales, intelectuales y afectivos, que caracterizan a toda una sociedad o a un grupo social (...); es la manera que cada

30 Las siguientes ideas pertenecen a un texto inédito titulado "Reflexiones - Serie Cuadernos" (páginas 7 a 16), Escuela de Estudios Superiores de Policía, Centro de Pensamiento y Doctrina. Bogotá. Julio de 2009.

31 El General recuerda la etimología del término cultura: "Del latín cultura y éste a su vez de colere (habitar, laborar la tierra, proteger, honrar con adoración). ...Recordemos, -dice Gómez- que Honrar con adoración se convirtió en culto; habitar un lugar, en colono; laborar la tierra, en cultivar; y, en cultura todo lo que el hombre crea y recrea". 
cual tiene para dar respuesta a los desafíos de la existencia; todo saber y poder adquirido por los hombres para dominar las fuerzas de la naturaleza; todas las organizaciones necesarias para fijar las relaciones entre ellas; el conjunto de procesos históricos que tienden a la consolidación de sistemas de vida y de pensamiento; La cultura consiste en pautas de comportamiento, explícitas o implícitas, adquiridas y transmitidas mediante símbolos y constituye el patrimonio singular de los grupos humanos (...)". En síntesis, estas nociones permiten inferir que para Gómez Padilla la policía como institución humana, no es un producto espontáneo, sino el resultado histórico de la voluntad humana, una creación cultural de la evolución social.

En segundo lugar, se refiere a “...la institución social Cuerpo de policía, como una agrupación humana organizada para realizar unos objetivos y fines, que posee jerarquías en sus funcionarios y división del trabajo, con lenguaje, símbolos, rituales, virtudes, valores, actitudes y sentimientos propios y a la cual se acogen voluntariamente sus integrantes y que no puede funcionar, si no existe consenso profesional entre sus miembros". Lo anterior señala que la cultura policial depende de la sociedad en la que está inmerso el cuerpo policial, el cual se constituye y reconstruye de generación en generación, mediante la interrelación de sus contemporáneos, sus antecesores y sucesores. "Por tanto, ella es el fruto de un proceso evolutivo continuo y no de una creación espontánea”.

En otro lugar ${ }^{32}$, Gómez se refiere a la "cultura policial local y universal", la cual está compuesta por el conjunto de principios de origen filosófico y los preceptos que surgen de la doctrina policial. Al respecto sostiene: “...los preceptos de obligatorio cumplimiento, en todo momento y circunstancias, deben ser interiorizados en los diferentes niveles jerárquicos y especialidades, de tal manera que nunca se olviden (...). De su aplicación se puede inferir que estamos en presencia de una institución democrática y profesional y sobre todo, respetuosa del estado social de derecho y de su propia civilidad. - Y menciona diez -: 1) Empleo de la fuerza y uso de las armas en forma reglada y limitada 2) Cumplimiento reflexivo de las órdenes 3) Igualdad ante la ley 4) Presunción de inocencia y buena fe 5) Respeto superlativo a los derechos humanos y al derecho internacional humanitario 6) Obediencia de las normas 7) Ausencia de cualquier forma de lucro en la función policial 8) Prevención como fundamento de su actividad 9) Privilegio de las libertades sobre la defensa del estado,

32 Gómez Padilla, Miguel Antonio (2009: 153 -154) Oraciones policiales. Bogotá, Colombia. Impresos y Copias. 
y 10) Respeto y sustento de la profesión en la ciencia policial (...constante en los currículos académicos)” (Gómez Padilla, M. A. 2009: 154).

\section{- Naturaleza civil de la policía}

En términos generales, para Gómez Padilla la naturaleza civil de la policía-cuerpo institución es ante todo un principio jurídico-político y por lo mismo de base constitucional, cuya esencia consiste en mantener las condiciones necesarias para el pleno ejercicio de los derechos y libertades públicas de las personas por encima del Estado. Esta situación reafirma la razón de ser y fin último del ente policía: el ser humano y la sociedad en convivencia armónica. "Civil" es una cualidad esencial de la policía opuesta a "militar". Sin embargo, el autor reconoce cierto origen militar de la Policía (...desde los ejércitos libertadores), un presente "híbrido" paradójico (civil, militar y judicial) a causa de la violencia y el conflicto armado colombiano que ha afectado la naturaleza civil de la institución, y un futuro de deber ser exclusivamente civil. Esta concepción de la naturaleza civil se afianza con la visión humanista de la Policía mediante su fidelidad a los preceptos constitucionales (Estado social de derecho) y la prevalencia de la vida y dignidad humanas.

\section{C) La Ciencia Policial desde el Derecho Administrativo. Mi- guel Alejandro Malagón Pinzón}

\section{- Origen del derecho administrativo}

La perspectiva desde el derecho administrativo de la ciencia policial de Malagón, puede ser vista desde dos ángulos, uno histórico y otro crítico político. En cuanto al primero, este autor sostiene que "el derecho administrativo colombiano se nutrió primigeniamente de lo que los alemanes llamaron la Ciencia de la Policía. Este Pensamiento que nos llegó -dice- por la vía de la península ibérica y de su sistema de administración" (Malagón 2009: $20^{33}$ ), es decir, contrario a lo que se cree en esta materia, la influencia liberal del derecho francés fue posterior.

En este sentido, respecto a los orígenes del derecho administrativo colombiano, este autor afirma: “... la policía fue, en su primera acepción, el método utilizado para imponer a los aborígenes americanos el estilo de vida

33 Malagón Pinzón, Miguel Alejandro (2009) "El régimen de los intendentes en la Constitución de Cúcuta de 1821: un modelo de administración policial en el estado republicano”. Ponencia presentada en el Primer Congreso Internacional de Ciencia de Policía, Octubre 28, 29 y 30 de 2009, Bogotá.

Policía Nacional de Colombia. 
europeo. Esta forma de control se transformó a finales del siglo XVIII en lo que hoy conocemos -dice Malagón- como civilización" (Malagón 2007: 301). Adicionalmente sostiene, que la relación entre policía y civilización en el siglo XIX fue una forma de implantar las instituciones de las misiones, las reducciones y los pueblos indios (2007: 301). En otras palabras, "vivir en policía" significó para el derecho administrativo colombiano el proceso de "civilización de indígenas", fenómeno atribuido a la Iglesia Católica, el cual pudo efectuarse también en otros países latinoamericanos. De este modo, es posible afirmar que la llegada de la antigua ciencia de policía al mundo hispanoamericano se produjo -consciente o inconscientemente- por dos vías: una política y otra religiosa.

En todo caso, el siglo XIX fue paradójico, como lo menciona el autor: "En el siglo XIX la policía padeció múltiples contradicciones fruto de la ideología liberal de que estaba imbuida. Porque algunas veces al pretender conservar y proteger los derechos individuales limitando su actuación, se generó un abuso de estas libertades y otras, porque ocasionó una acción ilimitada de la policía al demostrarse que los controles establecidos para contenerla resultaban insuficientes, debido a "los intereses políticos de quienes ostentaban el poder y disponen de la policía” (Malagón 2009: 7).

En cuanto al segundo, Malagón argumenta y demuestra que el sometimiento del poder político al Derecho no se produjo tras la Revolución Francesa y la separación de poderes, sino más bien, por el sometimiento de dicho poder al derecho en la legislación de Indias. En otras palabras, lo que señala este autor es un punto de crucial interés para el conocimiento actual de la ciencia policial: la tensión entre "Estado absoluto" y "Estado de derecho". Se entiende que en el primero el ejecutivo era el que administraba, legislaba, juzgaba, disponía de la hacienda y de la defensa del país, mientras en el Estado de derecho, la división de poderes hace que el ejecutivo sea controlado, se logra cierto equilibrio y se impide el "absolutismo". Entre tanto ¿̇ónde queda el poder de policía? ¿Qué tipo de ente policía emerge de uno u otro modelo de Estado?.

Malagón sospecha que a pesar de la desaparición formal del llamado "Estado absolutista", la tensión entre poderes y el sometimiento del ejecutivo al Derecho, fue, es y quizás sea, una dinámica de conflictividad permanente, más aún en sociedades cuyos procesos de democratización no sean contundentes o no se hayan consolidado. Es decir, según el tipo de Estado así mismo se configura el tipo de ente policía. En términos generales, se puede afirmar 
que Malagón a través de su exhaustiva revisión histórica sobre el origen del derecho administrativo en la antigua ciencia de la policía, da apertura a un campo de investigación crítico para la nueva ciencia policial, como es, las incesantes tensiones entre quienes ostentan la legitimidad de ejercer el poder y buscan servir sólo al Estado, y aquellos que intentan a través del conocimiento y la administración pública servir a la sociedad.

\section{- La ciencia de "vivir en policía"}

Si se acepta una inferencia de las ideas planteadas por Malagón, es claro que para este autor, la denominada "ciencia de la policía" transmitida a través de la conquista y colonia en la América Hispana, representó un proceso histórico de "civilización", entendida como la imposición a los aborígenes del estilo de vida europeo. "Vivir en policía" era vivir civilizadamente, cumpliendo de una parte, la doctrina Católica, y de otra, obedeciendo las ordenanzas de la Corona Española y así obtener la disciplina de los pobladores del nuevo reino. Dicho de otro modo, la relación entre policía y civilización durante los siglos XVII y XIX aproximadamente, constituye un atributo característico de la transición de cierto tipo de poder político-religioso hacia la configuración de los Estados republicanos en esta región del mundo ${ }^{34}$.

\subsection{LA CIENCIA POLICIAL EN MÉXICO. OMAR GUERRERO Y LA ADMINISTRACIÓN PÚBLICA}

La obra de Omar Guerrero representa para América Latina la perspectiva crítica de la ciencia policial desde la administración pública. Entre sus valiosos aportes, dos ideas inseparables articulan su círculo de argumentación para comprender qué fue y cómo puede ser el desarrollo de dicha ciencia: conocimiento y poder. En cuanto a la primera, Guerrero demuestra con detalle el origen que tiene la moderna administración pública en el seno del Cameralismo, exactamente, en la antigua ciencia de la policía (Polizeiwissenschaft). De este modo, la administración pública se plantea como sinónimo de conocimiento sobre el funcionamiento del Estado y la forma como éste se concibe técnicamente en acción. En cuanto a la segunda idea, la antigua ciencia de la policía deja como legado un nuevo arte de gobernar, una ciencia del poder, una ciencia del Estado, una ciencia

34 Si bien se puede especular que "la ciencia de civilizar" era equivalente a la "ciencia de policía" antes de la existencia del Estado de derecho, la propuesta de la nueva ciencia policial en la segunda mitad del siglo XX e inicios del XXI no es ajena del todo a la anterior idea, no obstante, en el marco de los derechos humanos y los derechos fundamentales que han de regir a las sociedades contemporáneas. 
política, con la capacidad de instrumentalizar el ejercicio de gobierno mediante una estructuración e implementación racional de reglamentos, procedimientos, técnicas y tecnologías al servicio del quien lo ostente.

Quedó claro, que aquello conocido como "administración pública" es herencia directa de la antigua ciencia policial procedente del Estado absolutista de los siglos XVII y XVIII, y que tal saber es quizás el eslabón perdido de las ciencias sociales. Desde este punto de vista, para el interés de la nueva ciencia policial situada en el ámbito de las instituciones de policía del siglo veintiuno XXI, el entendimiento respecto a la relación entre conocimiento y poder, o, ciencia y política, es esencial. En efecto, la expectativa que las sociedades demandan de los cuerpos policiales y del ente policía en general, depende inevitablemente, del acuerdo entre gobernantes y gobernados: de un lado, del conocimiento que tengan las personas sobre el poder político, y de otro, del poder que implica dicho conocimiento.

Entre las obras más destacadas de Guerrero se hallan: Teoría administrativa de la ciencia política (1976), La administración pública del Estado capitalista (1979), El proceso histórico de la acción gubernamental (1982), Introducción a la administración pública (1984), Las ciencias de la administración en el Estado absolutista (1986), Los cultivadores mexicanos de la ciencia de la policía en el siglo XVIII (1986), y Estudio introductorio a Elementos generales de policía (1996). En estas tres últimas publicaciones, el autor explícitamente expone la concepción que se tuvo sobre la ciencia de la policía en Alemania con el Cameralismo, en Francia y España.

Muy probablemente inspirado por Michel Foucault ${ }^{35}$, Guerrero acuña el tema del poder como base de la administración de los asuntos públicos, y llama la atención indirectamente sobre una noción muy en boga: el concepto de políticas públicas. La criticada "razón de Estado" apoyada en la tecnología del poder, en cierta medida conduce a la necesidad que tienen los estados modernos de instaurar, fortalecer, o, en algunos casos, recuperar su legitimidad ante la sociedad, y para ello, la acción gubernamental visible o publicitada (política pública), surte un efecto práctico sobre los gobernados. La combinación de las lógicas técnica (administración) y política (poder) son en suma, antecedentes claves de la ciencia policial para el mundo del siglo XXI.

35 Según Armando Suárez, Omar Guerrero comenzó a ocuparse del tema (administración - poder) estimulado por un artículo de Michel Foucault titulado "El origen de la tecnología del poder y la razón de Estado" (Ver presentación de Las ciencias de la administración en el Estado absolutista (1986: 20), Fontamara, México D.F.) 


\subsection{LA CIENCIA DE POLICÍA EN PERÚ. GUILLERMO HINOSTROZA}

En el año 2005 la Policía Nacional del Perú mediante acto administrativo publicó un libro titulado "Fundamentos de Doctrina y Ciencia policial". Su autor, Guillermo Hinostroza Rodríguez, general retirado y profesor de la Escuela Superior de Policía. Se trata de un texto concebido oficialmente como "un aporte epistemológico al estudio e investigación para formular, desarrollar, consolidar y difundir la doctrina y ciencia policial". Este fin institucional lo define como un texto cátedra para la formación del cuerpo de policía del Perú.

La perspectiva peruana sostiene que "Ciencia policial es el conjunto de conocimientos ordenados en forma metodológica y sistémica, que el policía trata de analizar e investigar científicamente los hechos que conoce para encontrar la verdad y lograr su finalidad teleológica de dar seguridad y tranquilidad en la convivencia social de la comunidad" (Hinostroza G. 2005: 222). En otros términos, "la ciencia policial es ciencia fáctica, vale decir, aplicativa o pragmática, porque se refiere a hechos y se orienta a la consecución de la verdad. -Y continúa- Nuestra disciplina como ciencia, es socio-técnica por razón de su propia naturaleza, cuyo estudio corresponde también a la filosofía policial, que analiza la razón, causa y origen de la función policial que cumple la Policía Nacional al servicio de la comunidad" (222). De lo anterior se infiere, que la ciencia policial tiene como objeto de estudio los hechos propios de la función policial, y su método es la investigación desde la realidad social cuyo fin es el servicio a la comunidad.

"La justificación (del anterior concepto) radica esencialmente en que el quehacer policial se refiere a hechos que se conocen en el servicio policial, pero, estos mismos hechos son también las características de las ciencias fácticas, por lo tanto, las ciencias policiales son ciencias fácticas. Por esta razón nuestra doctrina policial -se afirma- se sustenta en su propia naturaleza, en la función policial y en los fines constitucionales como de su Ley Orgánica y no en fundamentos diferentes a su propia realidad. Es evidente que el Estado delega a la Policía Nacional la facultad de brindar protección y seguridad a través de la función policial. La función policial cuando se materializa como servicio es objetiva y real, coherente con su finalidad teleológica; ella existe dentro de la sociedad y procura la convivencia armónica de los hombres para que exista orden, paz y desarrollo socio económico” (223). 
Como fundamentos de la ciencia policial, Hinostroza plantea que "la verdadera estructura de la ciencia policial radica en su propia naturaleza, en sus normas, principios y valores, finalidad constitucional, derechos humanos, cultura organizacional, trayectoria histórica, costumbres y tradiciones (...). Bien dicen los analistas de doctrina policial que en materia de Policía todo gira a través de la función policial, que por su carácter social y humanista que realiza y de los fines que persigue al servicio de la sociedad está llamada a lograr una destacada proyección científica en el ámbito social” (223).

En cuanto al método, el texto no expone directamente una forma en que se desarrolle la ciencia policial. De este modo el libro pregunta y responde: "¿Cómo estudiar la ciencia policial? El estudio e investigación de la ciencia policial se encuentra en un proceso de formulación y desarrollo con planteamientos conceptuales que se irán madurando en la medida que los estudiantes tomen conciencia del rol que nos compete como investigadores científicos de nuestra realidad policial y de lo que la sociedad requiera de su policía para su seguridad y protección" (224).

Finalmente, la contraposición que el autor hace entre "ciencia policial" y "ciencias policiales específicas" la absuelve del siguiente modo: "Hemos expresado que la ciencia policial se sustenta básicamente en la función policial como doctrina fundamental de nuestro quehacer. Ella emerge de nuestra propia realidad en forma objetiva y veraz. En este sentido la Policía como actividad profesional es una sola, tiene unidad, es dogmática, pragmática y holológica. De otra parte, la profesión policial para su mejor desempeño al servicio de la sociedad fragmenta o desdobla sus actividades en funciones específicas, llamadas especialidades las que a su vez tienen sus propios principios y normas que orientan su accionar. Estas especialidades hacen que la doctrina policial sea más dinámica y objetiva (...) y se integran a la ciencia policial y por eso se dice que existen ciencias policiales especializadas o específicas. Para todo policía primero su doctrina y después su especialidad. Dentro de las diferentes especialidades están (225): Orden y seguridad, Criminalística, Investigación criminal, Administración policial, Inteligencia policial. El libro de Hinostroza está dividido en dos partes y enumera catorce capítulos a través de los cuales desarrolla las ideas antes mencionadas. 


\title{
6. La Ciencia Policial desde la Filosofía Política
}

\author{
"Sostengo que, a diferencia de lo que afirma el relativismo, hay un \\ criterio objetivo y universal dado, a saber: un régimen politico es mo- \\ ralmente legitimo si y solo si ayuda a sus súbditos a satisfacer sus ne- \\ cesidades básicas y aspiraciones legitimas, las que pueden satisfacerse \\ sin poner en peligro el bienestar de los demás. En otras palabras, las \\ leyes buenas y los Gobiernos que las mantienen son aquellos que nos \\ ayudan a vivir razonablemente bien y juntos, si bien no en armonia, \\ por lo menos en paz" (Mario Bunge 2009)
}

La ciencia de policía en América Latina es la oportunidad histórica para que cada nación piense cómo mejorar las relaciones entre su Estado y la Sociedad. Al inicio de este artículo se advirtió sobre el origen de ese fenómeno histórico-político denominado ente policía, y cómo la noción de "policía" significó una concepción relativa a la organización de las sociedades humanas, a partir de la cual, se buscaba el orden, el bien común, el bienestar y la felicidad de las personas. En efecto, el cambio paradigmático del "Estado monárquico" hacia el "Estado de derecho" transformó esas relaciones: ahora cada cual se ocupa de buscar su "propia felicidad" sin importar la de sus congéneres, y el actual deber del Estado en las democracias liberales, consiste en garantizar el pleno ejercicio de las libertades individuales y la protección de los derechos. En pocas palabras, se puede afirmar que el decimonónico ideal de libertad en gran medida se ha cumplido, mientras que los ideales de "igualdad" y "fraternidad" poco o nada se han realizado.

Por ejemplo, de los 550 millones de habitantes de la región, 182 millones están en nivel pobreza y 71 millones padecen miseria ${ }^{36}$, y en estas condiciones, es muy difícil sostener que exista plena convivencia pacífica y que los problemas sociales (violencia, delincuencia, criminalidad, corrupción...) están bajo control del Estado. Entonces épor qué y para qué hablar de ciencia de policía en este contexto?. Si bien la respuesta a esta pregunta necesita más espacio, los planteamientos anteriores no son extraños ${ }^{37}$, y por el contrario, giran alrededor de la necesidad de generar el conocimiento científico suficiente para ayudar de alguna manera en los impactos adversos de los dos últimos ideales frustrados.

En esta dirección, la ciencia policial aspira ser el estudio de los problemas humanos que afectan la convivencia y las soluciones que le competen al ente policía. Dicho ente se concibe materializado en el modelo

36 CEPAL Informe 2008.

37 Se hace referencia a los puntos 4 y 5 de este artículo. 
Estado de derecho, y en su sentido unívoco de respeto a la vida y protección de la dignidad humana. El ente policía, cuya naturaleza es civil o socio-estatal a la vez, procura -ya no la otrora "felicidad de los súbditos"- sino el desarrollo humano, y necesita producir una nueva ciencia política, una nueva ciencia humana capaz de contribuir a la convivencia entre las personas, e incluso mejorar la coexistencia entre los mismos Estados. Puede sonar ambiciosa esta aspiración, pero entre más aumentan las dificultades humanas, más se hace evidente la urgencia de un conocimiento científico sobre las condiciones que hacen posible la convivencia y la paz.

En consecuencia, es indudable que la nueva ciencia de policía escudriñe sus principios fundamentales en la filosofía política. Pero esta filosofía no es la historia del pensamiento político (sin ignorarla), sino más bien, es el surgimiento de paradigmas cognoscitivos para comprender con mayor precisión las causas de los problemas y los conflictos que transforman la reorganización de las sociedades transmodernas ${ }^{38}$. En palabras sencillas, se trata de una ciencia con conciencia política del poder de sus hallazgos: no es la panacea para todos los males terrestres, pero si es el abordaje sistemático y sistémico de las causas de los problemas más acuciantes del ser humano integralmente.

La ciencia policial convoca y reúne a diferentes disciplinas para que las ciencias disminuyan su aislamiento multidisciplinario y dialoguen entre sí. Esta actitud epistemológica es valiosa para hallar soluciones frente a los problemas humanos mediante: visiones de conjunto, lograr no sólo comprensiones holísticas, sino además obtener explicaciones sistémicas para anticipar y prevenir eventos catastróficos, y facilitar la formulación e implementación de políticas prospectivas en la configuración de un mundo mejor. No obstante, los grandes problemas de la humanidad son asumidos de forma diferente según el tipo de ente policía, es decir, de acuerdo al modelo de Estado y su tendencia ideológico política. Este es el siguiente punto mencionar.

\section{I LOS GRANDES PROBLEMAS HUMANOS}

Seis enormes problemas convulsionan a la humanidad desde hace siglos, pero ellos se han intensificado en los últimos cien años, y particular-

38 "Sociedades transmodernas" significa aquellas que además de compartir principios como la libertad, la autonomía, el autodesarrollo y el autogobierno, van más allá del particularismo colectivo, y consideran que "no todo vale", y por tanto, la humanidad debe construir consensos universales a pesar de un mundo multicultural y tendiente al libertarismo. 
mente en el siglo veinte XX y en la primera década del XXI. El primero y más antiguo, es la pobreza, entendida como la débil capacidad que tienen los humanos para satisfacer sus necesidades básicas de subsistencia (alimento, salud...) y protección (vivienda, seguridad...). De los casi siete mil millones de habitantes del planeta, más de la mitad subsiste con estas limitaciones. La pobreza también es sobrepoblación sin recursos suficientes, desempleo, desigualdad económica y marginalidad. De los 550 millones de habitantes de América Latina, 182 están en condiciones de pobreza y 71 millones padecen miseria (hambre y sobrevivencia crítica) ${ }^{39}$.

El segundo es la violencia, inherente a la primitiva naturaleza humana, entendido como toda aquella forma agresiva de intolerancia e irracionalidad brutal, en la cual no hay respeto por la vida o esta carece de valor por parte de quienes la acechan ${ }^{40}$. La violencia se expresa en el terrorismo, la criminalidad, el secuestro, la extorsión, la trata de personas, los conflictos geopolíticos, la intolerancia totalitaria, y la delincuencia callejera, entre otras formas.

El tercer campo de problemas consiste en las enfermedades a nivel masivo, denominadas pandemias por su alto grado de propagación mediante virus letales que viajan de persona a persona, de una región a otra y de un continente a otro. Los ataques biológicos también hacen parte de las amenazas vigentes. No obstante, faltaría incluir las patologías mentales que igual afectan la vida humana.

El cuarto, es el deterioro ecológico de los ecosistemas naturales, de los cuales depende la vida de la especie humana, visible en la tala indiscriminada de bosques y la contaminación de ríos, mares, suelos y atmósfera. La alteración drástica del clima y la pérdida de la biodiversidad son sólo dos ejemplos. A este problema se adicionan el tráfico de especies y todos los impactos negativos causados por la acción humana irracional sobre su entorno natural. La escasez de agua en muchos lugares y la fatiga del suelo fértil ya generan conflictos entre humanos.

El quinto corresponde a lo que se denomina corrupción, entendida como aquella mentalidad y práctica depredadora de humanos entre sí cuyo ac-

39 CEPAL Informe 2008.

40 El armamentismo convencional y nuclear, la sofisticación tecnológica de las guerras, y el hiperterrorismo a toda escala se hallan en esta categoría. Ver por ejemplo, Ramonet, Ignacio (2004) Las guerras del siglo XXI. Editorial De Bolsillo, Barcelona España. Y de este miso autor (1999) Geopolítica del caos. Debate Madrid. 
cionar provoca el detrimento de la riqueza pública, y deteriora el valor público que las sociedades logran construir para el beneficio común. Además de los delitos contra la administración pública o el robo de recursos públicos, la corrupción en sentido amplio, es toda acción y efecto negativo contra la integridad y la moralidad de una persona o sociedad. En este sentido, la corrupción se expresa en la ilegalidad, la ingobernabilidad, la pérdida de legitimidad, el capitalismo salvaje, el predominio del egoísmo, el enriquecimiento ilícito, y el tráfico de armas, drogas, órganos, insumos nucleares, y mano de obra.

Y el sexto problema, al parecer no causado por los humanos, son los desastres naturales. Si bien en diferentes épocas de la historia humana se han presentado grandes hecatombes, estas tienden a ser más frecuentes y con períodos más cortos de tiempo. Se dice "al parecer" porque hay dos causas: las antrópicas o provocadas por el humano, y las no antrópicas o por causas naturales propias de la evolución cósmico-planetaria. En el primer caso, se hace referencia a la alteración del clima y la afectación de la naturaleza por causa de la industrialización y urbanización del mundo. En el segundo caso, se alude a fenómenos como los terremotos y cataclismos similares de carácter impredecible, y de alto impacto en las estructuras materiales y culturales de las sociedades.

En resumen existen catástrofes de dos tipos: naturales y humanas. Ya en los años setenta 70s intelectuales críticos de la cultura occidental sostenían: "La crisis actual avanza hacia un punto en el que o bien nos enfrentaremos con una catástrofe natural o social, o bien, antes o después de esto, los hombres reaccionarán de un modo u otro y tratarán de establecer nuevas formas de vida social que tengan un sentido para ellos. Esto no podemos hacerlo por ellos ni en su lugar; ni tampoco podemos decir cómo se podría hacer. Lo único que está a nuestro alcance es destruir los mitos que, más que el dinero y las armas, constituyen el obstáculo más formidable en la vía de una reconstrucción de la sociedad humana ${ }^{41}$ " (Castoriadis, Cornelius 1979: 209). Décadas después se observa la recurrencia de estas catástrofes a medida que el planeta padece una sobrepoblación que supera la oferta de recursos naturales no racionalmente administrada.

\subsection{LÍMITES DE RESPONSABILIDAD DEL ENTE POLICÍA ANTE LOS PROBLEMAS HUMANOS}

Si el ente policía es una complejidad institucional-estatal y social, es posible afirmar que de modo directo e indirecto si existen grados de respon-

41 Attali, Castoriadis y otros (1979) “El mito del desarrollo”, Editorial Kairós, Barcelona España. 
sabilidad alta, media o baja en la encrucijada de los problemas humanos que alteran con adversidad la convivencia. Cabe preguntar luego: ¿Tienen importancia los problemas para el ente policía y su ciencia? ¿Qué puede hacer la ciencia de policía frente a las causas y los efectos de los problemas humanos? ¿Debe hacer algo? ¿Puede hacerlo? ¿Con qué limitaciones y alcances? ¿Es de su competencia generar conocimiento sobre tales problemas? ¿Qué tipo de problemas puede y debe la ciencia policial encarar especialmente? ¿Cuáles problemas afectan más la vida social que otros? ¿Todos los problemas afectan? ¿Qué rol cumple la función policial de los cuerpos de policía en el contexto problemático descrito?

La Figura 2 "Ciencia policial y problemas humanos" sugiere pensar por lo menos en tres ideas para orientar las cuestiones precedentes. En primer lugar, la doctrina, las políticas, las estrategias, los programas y las acciones del ente policía dependen del paradigma de pensamiento predominante en un momento histórico. En el caso del mundo actual, todos los Estados promulgan el discurso del bienestar humano en medio de la intrincada pugna entre interés general los intereses particulares, sea cual sea la tendencia ideológico política.

Entre tanto, se supone que las ciencias sociales de alguna manera aportan ideas para ese bienestar, pero entre ellas, la de policía, -antiguamente ciencia del Estado-, tiene ese especial deber: su construcción en el siglo veintiuno XXI obedece al paradigma de un mundo mejor edificado con conocimiento y conciencia planetaria, formalmente expresado en los derechos del ser humano a su desarrollo integral, el respeto a su vida y dignidad, y su participación en el disfrute de la prosperidad material y espiritual, según la sociedad y la cultura a la que pertenezca.

Figura 2: Ciencia policial y problemas humanos

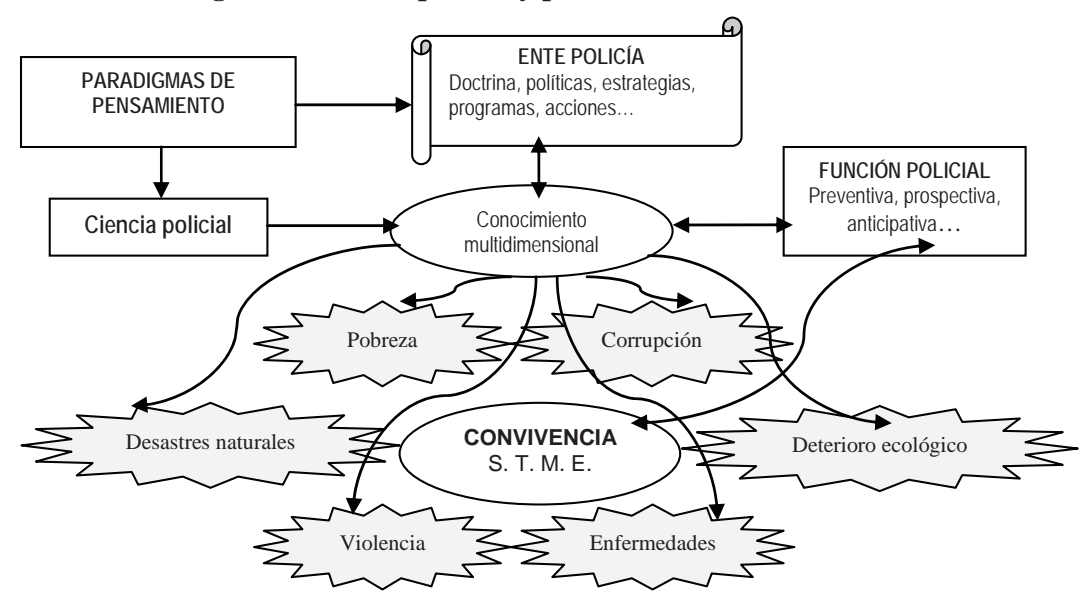

Fuente: Suárez A. Jairo E. (2009) 
En segundo lugar, las instancias que componen el ente policía (quienes regulan, administran y ejecutan...), necesitan desarrollar ciencia policial con la meta de producir conocimiento multidimensional en permanente actualización, dada la velocidad de los cambios en la información sobre los procesos sociales y la multicausalidad y multiplicidad de efectos problemáticos en la convivencia. El objetivo es determinar visiones de conjunto o diagnósticos complejos, que faciliten la comprensión sencilla y la explicación clara y oportuna de los fenómenos afines a la función policial, mediante las acciones necesarias y suficientes (estrategias, programas...). Y en tercer lugar, los cuerpos de policía desde su competencia otorgada por la doctrina, las políticas y demás principios, han de ejecutar con mayor intensidad una función policial más prospectiva y anticipativa frente a los riesgos y las condiciones de vulnerabilidad que acechan en aumento la convivencia.

De acuerdo a las anteriores ideas, una de las tareas importantes de la ciencia policial es determinar los límites de responsabilidad del ente policía ante los mencionados problemas humanos. Se hace referencia a la tensión entre conocimiento y poder en cuanto al grado de participación y aporte de cada especialidad científica en la solución de un problema. Por ejemplo, si bien hay diferencia entre la tala de árboles (destrucción de la selva) y un genocidio (exterminio de un grupo), las dos acciones cometidas por el humano implican responsabilidades distintas del Estado y su ente policía. En el primer caso, el gobierno enfrenta el dilema de apoyar la industria de la madera, no afectar el trabajo de muchas familias que viven esa explotación de recursos naturales, y al tiempo, proteger los ecosistemas y el ambiente natural. En el segundo caso, el gobierno tiene la obligación inmediata de identificar, procesar y juzgar a quienes hayan cometido tal magnicidio.

Visto de otro modo, el núcleo común de los dos problemas es la convivencia: por una parte, porque el deterioro ecológico genera conflictos entre los humanos (por las fuentes de energía y sustento como el agua, obtención de energía, alimento, trabajo...), y de otra, porque la desaparición y asesinato de personas destruye la convivencia misma. En el Cuadro "Problemas humanos y convivencia" se sugiere la multiplicidad de implicaciones entre los grandes problemas y sus efectos directos e indirectos en la convivencia, respecto a lo cual se necesita suficiente conocimiento sistemático para discernir y lograr 
identificar los límites y competencias de actuación del ente policía frente a dichos problemas.

Del ejemplo anterior, se puede inferir lo siguiente sobre la responsabilidad del Estado a través del ente policía. En primer lugar, tanto la destrucción de la selva como el exterminio de un grupo de personas, son delitos, aunque de diferente naturaleza: el primero es un delito ecológico-ambiental y el segundo un delito de lesa humanidad. Juntos afectan la convivencia. De un lado, la violencia (genocidio...) afecta la seguridad, deteriora la moralidad pública (en el sentido gubernamental), altera la tranquilidad, y puede, eventualmente, destruir los ecosistemas (mediante la explosión de oleoductos por saboteos guerrilleros, accidentes nucleares inducidos, derrames de petróleo crudo en el océano, atentados terroristas...). De otro lado, el deterioro ecológico (tala de árboles...) incide en primer plano en la salud del medio ambiente, pero además, puede afectar la seguridad humana, la moralidad y también la tranquilidad.

Problemas humanos y convivencia

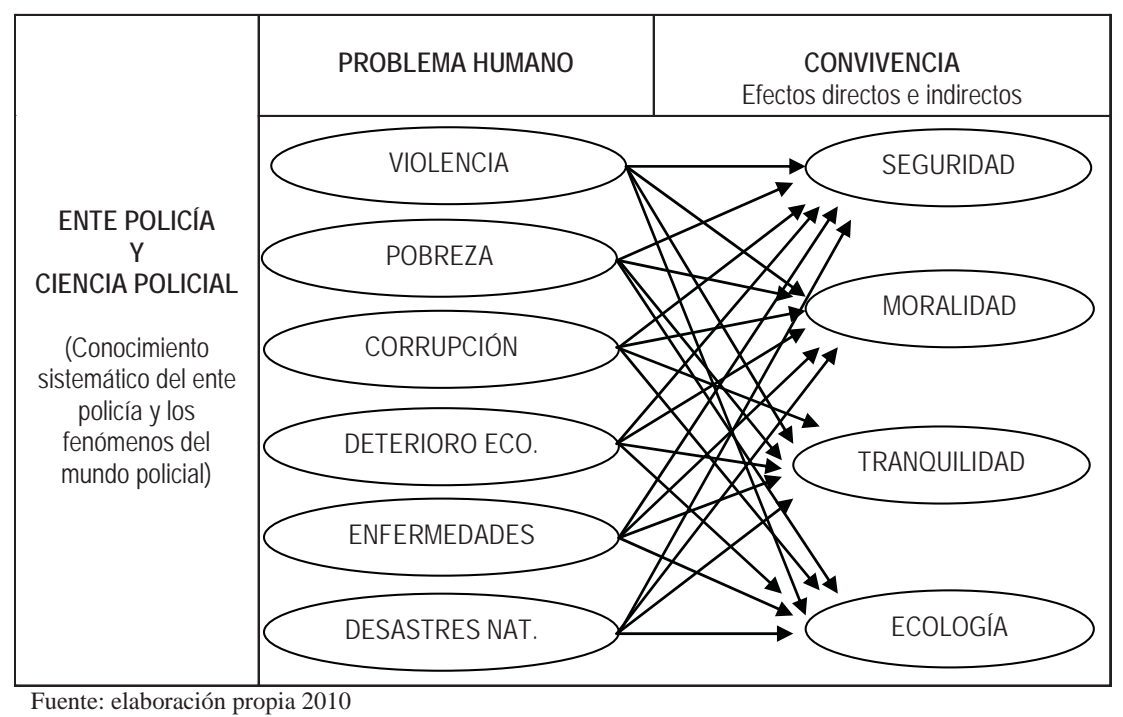

Estos ejemplos son una pequeña descripción de la compleja encrucijada en que se encuentra inmerso el Estado y el ente policía, razón que demuestra la trascendencia y necesidad del conocimiento científico policial cuyo reto consiste en armonizar las relaciones sociales (convivencia), el poder y la ciencia. Sin embargo, en esta labor las tendencias de pensamiento político cumplen una función determinante. Este es el último punto por mencionar. 


\subsection{TENDENCIAS DE PENSAMIENTO POLÍTICO Y EL ENTE POLICÍA}

Los modelos policiales -centrados en el Estado o centrados en la Sociedad $^{42}$ - dependen directamente de las tendencias de pensamiento político. Su doctrina está determinada por la ideología política predominante en un momento dado, es decir, un modelo policial estructura su régimen, su poder y su función según el tipo de gobierno. En el caso colombiano un notable político resumió este asunto así: "Habrá buena o mala policía si hay buen o mal gobierno ${ }^{43}$ ". Aunque esta frase pertenece a otro contexto, sugiere la relación inherente entre política y policía, entre teoría y práctica. Entre tanto, desde este punto de vista, los diferentes problemas humanos que enfrentan los gobiernos adquieren una orientación especial con relación a la convivencia. Por ejemplo, un gobierno puede permitir que cierta comunidad viva de la explotación forestal desmedida en detrimento del equilibrio ecológico, o bien, por razones electorales o incapacidad de facilitar otras alternativas de empleo y subsistencia. Es decir, puede configurarse un "socialismo anti-ecológico" o lo contrario. Todo esto depende de las concepciones de individuo, de persona, de sociedad y de Estado que conciban quienes desde el gobierno toman las decisiones públicas.

Ahora bien, según la Figura 3 cada tendencia de pensamiento político determina la naturaleza del ente policía y su expresión a través de diferentes modelos policiales. El modelo policial se concibe como el diseño doctrinario y estratégico que determina el régimen de policía, el poder de policía y la función policial tendientes a la convivencia. El modelo se plantea para enfrentar los problemas humanos que afectan la convivencia y sus categorías (seguridad, moralidad, tranquilidad y ecología). Simultáneamente, el pensamiento político influye en la ciencia policial, ante lo cual, el conocimiento multidimensional tiene el deber de retroalimentar al modelo, con el fin de incidir en la doctrina, las políticas, el ente y sus dinámicas respecto a los problemas.

42 Hay modelos policiales concebidos para servir más a los intereses del Estado, y otros de naturaleza civil orientados a servir a los intereses generales de la sociedad.

43 Alberto Lleras Camargo (1906 - 1990). 
Figura 3: Tendencias de pensamiento político y modelos policiales

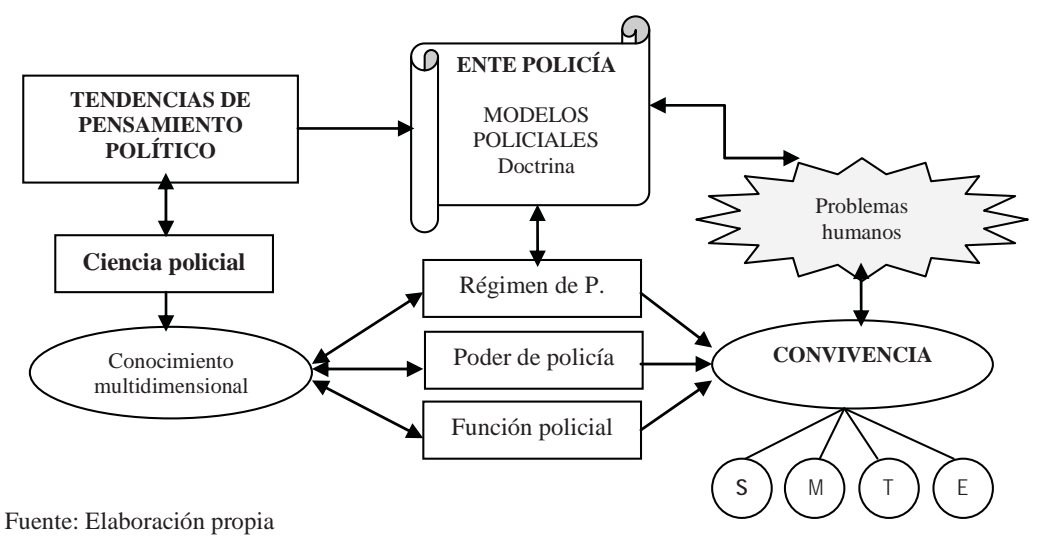

Con base en las ideas enunciadas, es oportuno formular algunos interrogantes: ¿Es posible una nueva ciencia política y social comprometida con resolver o mitigar los problemas humanos que afectan la convivencia? ¿Tienen fundamento científico las decisiones de gobierno? ¿Tienen fundamento científico las acciones del ente policía? ¿Qué implicaciones hay en la relación entre ideología política y ciencia? ¿Cómo se entienden los problemas humanos (pobreza, violencia, corrupción, ...etc) desde el liberalismo, el socialismo, el republicanismo etc.? ¿Qué rol juega en la encrucijada de los problemas humanos el ente policía? ¿Son coherentes los modelos policiales frente a tales problemas? Y en la diversidad del contexto latinoamericano ¿Cómo desarrollar la ciencia de policía desde las instituciones policiales para contribuir a la solución de los problemas que afectan la convivencia?

La última pregunta tiene una respuesta con un componente teórico y otro práctico. En cuanto al primero, es fundamental que los centros de educación y formación policial reflexionen sobre la relación entre policía, política y ciencia, y los efectos que la doctrina produce en la solución o no de los problemas que afectan a la sociedad. En cuanto al segundo, aunque los cuerpos policiales sean instituciones subordinadas al poder político de la administración pública, ellas no pueden ni deben ser simples instrumentos gubernamentales sin el conocimiento científico de su competencia: la ciencia de policía. Esta tesis solamente enunciada, implica un trabajo complejo e inaplazable para las policías del siglo XXI. 


\section{a) Gnoseología, ontología y deontología policiales}

Un punto de partida para avanzar en la anterior tarea, consiste en plantear los rumbos posibles que la ciencia de policía puede vislumbrar según las tendencias de pensamiento político, y la necesidad de desarrollar una filosofía policial con fundamentos ontológicos (el ser), gnoseológicos (el conocer) y deontológicos (el deber hacer) bien claros.

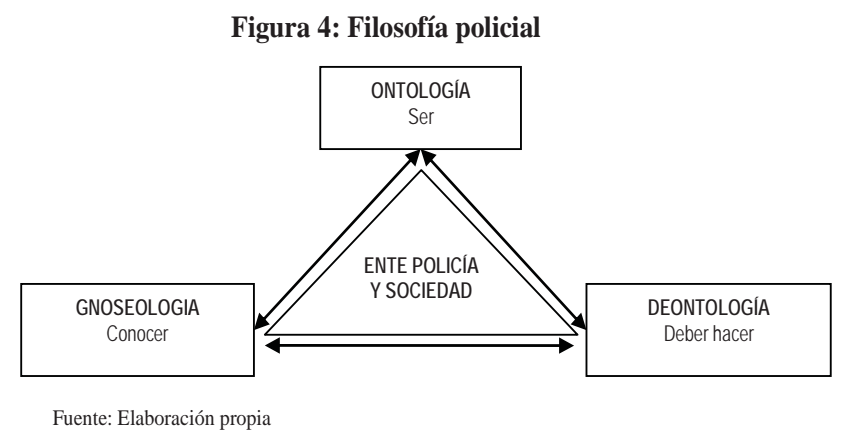

En la Figura 4, se menciona la interdependencia entre los fundamentos que constituyen toda filosofía y ciencia en sentido estricto. En primer lugar, la ontología policial significa e implica conciencia por parte del ente policía y la sociedad sobre la naturaleza del mismo ente: si es de naturaleza civil, de énfasis militar, armado, desarmado, criminológico, etc. Este componente determina la doctrina política, la filosofía institucional y el marco legal que otorga la identidad e identificación según los ideales sociales y el deber ser proclamado. En segundo lugar, la gnoseología policial significa el campo de conocimiento que el ente policía y la sociedad tienen de la realidad, es decir, las formas (ciencia, educación, creencias, cultura...) que producen las concepciones de individuo, persona, Estado y las relaciones entre el humano, sus congéneres y su entorno. Y en tercer lugar, la deontología policial significa ámbito práctico de los deberes de la función policial en la sociedad. El "deber ser" exige un "deber hacer": la doctrina y el conocimiento científico policial se materializan en las prácticas y en el trabajo cotidiano de la policía en la interacción Estado - Sociedad.

Cada uno de los anteriores fundamentos debe interpretarse de acuerdo al contexto del ente policía, razón que exige nuevamente analizar las diferentes tendencias políticas y las clases de ente policía que se configuran a partir de ellas. 


\section{b) Tendencias políticas y ente policía}

La siguiente descripción resume las tendencias de pensamiento político con relación al ente policía. La tesis consiste en afirmar que el ente policía adquiere su configuración jurídico-política o su doctrina según el significado y el sentido que le imprime cada uno de los núcleos filosóficos de la respectiva tendencia (Ver Matriz final). Como se aprecia, el liberalismo, socialismo, republicanismo, comunitarismo y conservadurismo, de acuerdo a sus énfasis de concepción filosófica, generan supuestos de doctrina que constituyen a su vez la naturaleza del ente policial. De forma directa e indirecta, a favor o en contra, las tendencias políticas influyen de modo determinante en el fin de la ciencia policial, es decir, en la convivencia. Al fin y al cabo, todo pensamiento político contiene una representación mental del individuo, la sociedad y el Estado, y dentro de éste, las instituciones y significaciones que rigen o han de regir la vida humana.

Sin embargo, la clasificación de estas tendencias de pensamiento político advierte sobre los siguientes supuestos. En primer lugar, la relación entre policía y política se explicita en cada tendencia, tanto desde el punto de vista ideológico como doctrinal, es decir, las concepciones de sujeto, sociedad y Estado determinan el modelo policial. En segundo lugar, las tendencias no son estáticas ni puras, porque en la realidad se generan híbridos o mezclas entre unas y otras con apariencia contradictoria: por ejemplo, un ente policía inspirado en una revolución socialista combinada de republicanismo comunitario, el cual recurre a la expropiación de bienes privados bajo el argumento de la igualdad y la justicia re-distributiva de la riqueza común.

En tercer lugar, el ente policía derivado de una tendencia se materializa y expresa mediante prácticas tangibles en la vida de la sociedad, por ejemplo, la regulación de las libertades, el comportamiento permitido (moralidad...), las restricciones respecto al entorno natural (ecología...), entre otros aspectos. En cuarto lugar, unas categorías del ente policía (régimen, poder y función) dependen directamente del paradigma de pensamiento, porque una cosa es un régimen de policía en un Estado socialista que en uno liberal, o bien diferente es un modelo policial comunitario en un Estado democrático que en aquel que impone un predominio de raza, cultura y mentalidad. A continuación se hace alusión a cada una de las concepciones sobre el ente policía de acuerdo a cada tendencia ${ }^{44}$.

44 El lector advertirá que no se han incluido tendencias políticas basadas en el fundamentalismo religioso, dado que el concepto de "ente policía" se identifica más con concepciones de las sociedades occidentales. Se advierte también que la síntesis de cada una de las ideologías mencionadas es sólo descriptiva y genérica, y el autor las desarrolla con más amplitud y rigor en otros trabajos (Suárez Alvarez, Jairo E. 


\section{- Ente policía según el liberalismo igualitarista}

Los supuestos de doctrina indican que el ente policía tiende a ser legal garantista, para el cual, los principios de igualdad en derechos y deberes, fraternidad y cooperación entre los miembros de la sociedad son prioritarios. El modelo policial se orienta a respetar al individuo en su libertad civil y propende por la justicia reparadora en su limitada competencia ante las inevitables desigualdades sociales.

\section{- Ente policía según el liberalismo democrático}

La doctrina liberal democrática concibe el ente policía al servicio y protección del orden jurídico-político en que prevale el respeto a las libertades individuales, los derechos y deberes con la Constitución. Los principios de pluralidad, tolerancia, soberanía popular y respeto a la ley inspiran modelos de policía democrática, a favor del gobierno representativo y la búsqueda de la convivencia garantizada.

\section{- Ente policía según el neoliberalismo}

El neoliberalismo o conocido también como liberalismo Libertarista sostiene la necesidad de reducir al mínimo el Estado y su capacidad de intervenir en la vida privada. Paradójicamente, reducir el Estado equivale a maximizar su función policiva, la cual consiste exclusivamente en garantizar la seguridad de proteger los derechos particulares como la propiedad, la libre empresa, y el cumplimiento de los contratos privados. El ente policía es sólo un ente vigilante y garante de la competitividad y la autonomía económica de los particulares.

\section{- Ente policía según el socialismo utópico}

Esta tendencia ostenta la supremacía de un ente policía "revolucionario" al servicio del régimen totalitario. Desde este enfoque, el uso de la fuerza por parte del Estado socialista es justificado en aras de la revolución, la igualdad absoluta, el rechazo de clases privilegiadas y el sometimiento sólo al poder del proletariado en manos de sus líderes insumisos. El ente degenera en el sentido equívoco (autoritarismo, arbitrariedad, abuso...).

\section{- Ente policía según el socialismo democrático}

En esta variante del socialismo el ente policía se concibe reformista, pues intenta conciliar el principio de igualdad colectiva con el de pluralismo.

(2006) Pensamiento político y desarrollo ciudadano, Universidad de los Andes, Bogotá Colombia). 
El modelo policial idealmente busca garantizar los derechos sociales, económico-colectivos, y culturales. Rescata la dignidad humana ante los acechos individualistas de intereses particulares.

\section{- Ente policía según el republicanismo}

En esta tendencia el ente policía es eminentemente político y garante de la participación ciudadana en los asuntos públicos. El modelo policial se orienta hacia la generación de conductas cívicas, y también garante de la seguridad de la vida, bienes y honra, para lo cual exige disciplina ciudadana e inculca los deberes y derechos que el orden constitucional demanda en la construcción de lo público.

\section{- Ente policía según el comunitarismo}

En el Estado comunitarista el ente policía se concibe como el medio para la unificación cultural y la construcción de identidad nacional, y así, fortalecer el sentido de pertenencia y arraigo a la comunidad. En lugar de individuo hay comunidad, y por ello, el modelo policial se convierte en protector de la identidad cultural comunitaria, la tradición, los valores prevalecientes y todo aquello que conviene a la convivencia comunal.

\section{- Ente policía según el conservadurismo}

Es posible inferir que el ente policía se concibe, según esta tendencia, como una autoridad de naturaleza política y en esencia ligado a la tradición, las costumbres y la moral heredada por la sociedad. Aunque en su versión antigua esta corriente no consideraba necesaria la teoría del contrato social ${ }^{45}$, su evolución en el siglo XX le condujo a comprometerse con los principios democráticos básicos del gobierno representativo, las elecciones y el Estado de derecho. No obstante, desde la óptica conservadora el ente policía debe hacer respetar las buenas costumbres, la moralidad, la tradición, la religión y la ley. Debe mantener el orden social, la justicia y evitar la tiranía de las élites sobre las masas desde un punto de vista paternal.

45 Como la perspectiva clásica del siglo XVIII en Inglaterra con Edmund Burke (1729 - 1797), quien en su obra "Reflexiones sobre la revolución en Francia" (1790), argumentó a favor de la tradición, las normas y la santidad de la ley y la autoridad, y advirtió contra la expansión gradual de la participación popular en los asuntos del Estado (Ver Macridis y Hulliung (1998: 97 - 111). Esto se debe a que la mayoría de conservadores no acepta que el pueblo o las clases bajas accedan al poder político, pues sólo los mejores y más preparados por herencia o tradición deben gobernar. 


\section{c) Algunas implicaciones}

Ahora bien, es necesario comentar lo siguiente. En primer lugar, para el liberalismo el ente policía fundamenta sus supuestos de doctrina a partir del énfasis en los derechos individuales de las personas. Por tanto, es un ente legal que pretende garantizar el pleno ejercicio de las libertades e interviene con prudencia y límite jurídico en los ámbitos privados de la vida de los sujetos. En segundo lugar, a medida que aumenta el grado de intervención del Estado en la vida de los individuos, aumenta el riesgo de deslegitimación de la acción policial-estatal, dada la vulneración de los derechos a la libertad en el umbral de lo público/privado.

En tercer lugar, la combinación ideal para concebir un ente policía equilibrado consiste en extraer los principios de doctrina que eviten los extremos ideológicos: ni un Estado mínimo indiferente a las desigualdades sociales o defensor del individualismo egoísta, pero tampoco totalitario que desconozca la prevalencia de la dignidad humana, el pluralismo, y la importancia del derecho para garantizar la armonía entre libertad e igualdad cuyo fin haga sostenible la convivencia democrática.

También es preciso señalar, que el conservadurismo (o conservatismo) es y ha sido una actitud de mantener a toda costa, bien sea el poder político, económico, de privilegios, etc. En esta medida, es una ideología transversal aplicable a las demás tendencias políticas, porque tanto el liberal como el socialista querrán "conservar" su estatus o permanencia en el poder. En conclusión, los modelos policiales dependerán de la tendencia política que cada Estado y sociedad sustenten en la búsqueda de la legitimidad, el orden deseado y la convivencia.

\section{Comentarios Finales}

\section{El punto de vista ontológico}

El ente policía es un fenómeno histórico-político de naturaleza cívico-estatal. Este concepto expuesto demuestra que "policía" es una noción con diferentes sentidos (multívoco, equívoco, unívoco) y dimensiones (política, social, cultural...), y de esta forma, contiene un modo de ser de acuerdo a la sociedad a la que pertenece. Por esta razón, la ciencia de policía en Amé- 
rica Latina es una alternativa para perfeccionar (o en algunos casos reformar) las instituciones policiales que intentan servir a la sociedad. ¿Qué deben ser y cómo deben ser los cuerpos policiales según las necesidades y problemas humanos que enfrentan?. La doctrina policial (su identidad) es un objeto de estudio relevante en el contexto de las tendencias políticas y las relaciones entre policía, política y sociedad.

\section{El punto de vista gnoseológico}

La policía necesita desarrollar su ciencia. Las instituciones policiales de América Latina necesitan producir mayor conocimiento científico para hacer mejor su trabajo. El conocimiento que tienen las organizaciones policiales sobre la sociedad, debe convertirse en conocimiento científico policial. Para este propósito, se deben articular las diferentes especialidades policiales en un sistema de conocimientos denominado ciencia de policía. En este sentido, se ha afirmado que la ciencia de policía tiene por objeto el estudio de los fenómenos del mundo policial que el ente policía enfrenta para resolver los problemas humanos que afectan la convivencia (seguridad, tranquilidad, moralidad y ecología). Ahora bien, según se propuso al inicio, se ha demostrado que la relación entre filosofía política y ciencia policial adquiere importancia creciente para mejorar la convivencia, tanto al interior de cada país, como de cada uno con la comunidad internacional de naciones. En la medida que los actuales Estados de derecho afinen sus procesos de toma de decisión a partir de criterios científicos en armonía con sus tendencias ideológico-políticas, quizás la probabilidad de construir un mundo mejor aumente, y la prospectiva de la creatividad humana logre traducir la información en conocimiento, y éste, en políticas o acciones prácticas y sencillas para la convivencia.

\section{El punto de vista deontológico}

El deber ser exige un deber hacer. En esta medida, si la policía tiene clara su naturaleza o modo de ser (ontología) y desarrolla su conocimiento científico (gnoseología), su misión en la sociedad será más coherente con el sentido unívoco del ente policía (deontología). Los cuerpos de policía cumplen con sus deberes misionales porque los comprenden no sólo ética sino científicamente. Desde esta perspectiva, los modelos policiales toman como fin a la persona en su entorno social, y el Estado de derecho puede fortalecer sus principios constitucionales por medio de la articulación entre ley, moral y cultura. Si la comunidad de Policías latinoamericanas afianza su identidad 
en medio de la diversidad cultural por medio del desarrollo de la ciencia policial, es muy posible entonces, que la identificación de los problemas humanos confluya en problemas comunes: por ejemplo, la transnacionalización de crímenes y delitos de diversa índole (el narco-terrorismo...), situación que demanda mayor cooperación e intercambio de avances científicos para enfrentar las crisis.

Como punto final, los estudios descritos sobre ciencia de policía en América Latina corresponden a tres avances elaborados por organizaciones policiales (Argentina, Colombia y Perú), y uno desde la administración pública (México). Falta sumar luego, los numerosos estudios sobre policía, para que la construcción de la nueva ciencia policial profundice y acelere las tareas pendientes ${ }^{46}$.

Matriz: Tendencias políticas y ente policía

\begin{tabular}{|c|c|c|c|c|c|}
\hline 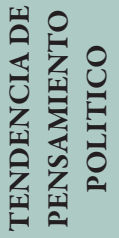 & 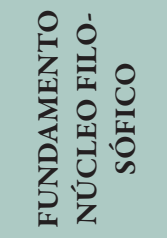 & SUJETO & SOCIEDAD & ESTADO & $\begin{array}{l}\text { ENTE POLICÍA } \\
\text { (Supuestos de } \\
\text { Doctrina) }\end{array}$ \\
\hline \multirow{3}{*}{ 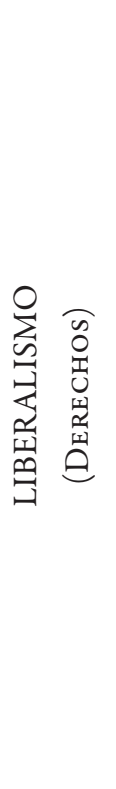 } & $\begin{array}{c}\text { A } \\
\text { IgUAlita- } \\
\text { RISTA } \\
\text { (Tipo Rawls) }\end{array}$ & $\begin{array}{l}\text { Individuo } \\
\text { libre civil y } \\
\text { políticamente, } \\
\text { en igualdad, } \\
\text { solidario } \\
\text { (Fraterno) }\end{array}$ & $\begin{array}{l}\text { Regulada por } \\
\text { principios de } \\
\text { Justicia. Justifica } \\
\text { desigualdades. } \\
\text { Cooperativa }\end{array}$ & $\begin{array}{l}\text { Neutral, interventor, } \\
\text { de Bienestar, "Repa- } \\
\text { rador", aplica "Justicia } \\
\text { distributiva". Busca } \\
\text { consensos }\end{array}$ & $\begin{array}{l}\text { LEGAL GARANTISTA: } \\
\text { Igualdad en } \\
\text { derechos y deberes. } \\
\text { Fraternidad, libertad. } \\
\text { Cooperación, sentido } \\
\text { de justicia y civismo }\end{array}$ \\
\hline & $\begin{array}{c}\text { B } \\
\text { DemocRÁ- } \\
\text { TICO }\end{array}$ & $\begin{array}{l}\text { Individuo libre } \\
\text { en la pluralidad, } \\
\text { respetuoso de la } \\
\text { ley (tolerante) }\end{array}$ & $\begin{array}{l}\text { Pluralista, } \\
\text { con gobierno } \\
\text { representativo, } \\
\text { conjunto hom- } \\
\text { bres libres }\end{array}$ & $\begin{array}{l}\text { Neutral, interventor } \\
\text { moderado, } \\
\text { Constitucionalista. } \\
\text { Fines = convivencia } \\
\text { democrática }\end{array}$ & $\begin{array}{l}\text { LeGal Democrá- } \\
\text { TICO, Prevalece } \\
\text { soberanía popular, } \\
\text { respeto a libertades, } \\
\text { DERECHOS y } \\
\text { deberes }\end{array}$ \\
\hline & $\begin{array}{c}\text { C } \\
\text { LIBERTA- } \\
\text { RISTA } \\
\text { NEOLIBERA- } \\
\text { LISMO } \\
\text { (TIPO } \\
\text { Nozick) }\end{array}$ & $\begin{array}{l}\text { Individuo libre } \\
\text { civil, política y } \\
\text { económicamen- } \\
\text { te: autónomo } \\
\text { absoluto } \\
\text { Fin en sí mismo } \\
\text { (Egoísta) }\end{array}$ & $\begin{array}{l}\text { Abierta, plura- } \\
\text { lismo fuerte, no } \\
\text { solidaria, Jus- } \\
\text { ticia histórica, } \\
\text { interés privado, } \\
\text { particular, } \\
\text { Competitiva }\end{array}$ & $\begin{array}{c}\text { Mínimo } \\
\text { No interventor } \\
\text { Sólo Vigilante: } \\
\text { Policía garante de } \\
\text { la seguridad contrac- } \\
\text { tual, la propiedad, } \\
\text { el libre mercado } \\
\text { y la competencia } \\
\text { individualista }\end{array}$ & $\begin{array}{l}\text { LEGALISTA VIGI- } \\
\text { LANTE } \\
\text { Para la seguridad po- } \\
\text { liciva, más derechos } \\
\text { que deberes. } \\
\text { Individualista } \\
\text { Restrictivo frente a } \\
\text { colectividad }\end{array}$ \\
\hline
\end{tabular}

46 Por ejemplo, se requieren a corto plazo por lo menos dos tareas. La primera, definir una Agenda regional respecto a las necesidades de conocimiento científico policial para abordar con una visión integral y global los problemas que afectan la convivencia; y la segunda, conformar y dinamizar una Red Internacional de Ciencia de Policía que aporte sobre la discusión epistemológica de la nueva disciplina, y para que su producción contribuya a la generación de doctrina, al intercambio de experiencias, el diseño de modelos policiales, y al robustecimiento teórico y práctico de la vida del ente policía en las sociedades del mundo actual. 


\begin{tabular}{|c|c|c|c|c|c|}
\hline 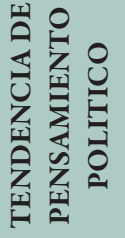 & 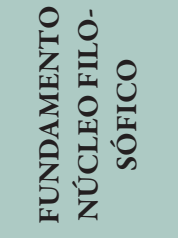 & SUJETO & SOCIEDAD & ESTADO & $\begin{array}{l}\text { ENTE POLICÍA } \\
\text { (SuPUESTOS de } \\
\text { Doctrina) }\end{array}$ \\
\hline \multirow{2}{*}{ 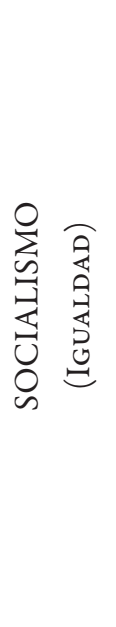 } & $\begin{array}{l}\text { UTópico } \\
\text { (T. Moro, } \\
\text { Bacon, } \\
\text { Campanella, } \\
\text { Proudhon) }\end{array}$ & $\begin{array}{l}\text { Colectivo, } \\
\text { no oprimido, } \\
\text { no explotado } \\
\text { no alienado } \\
\text { insumiso } \\
\text { anarco. Sin pro- } \\
\text { piedad privada }\end{array}$ & $\begin{array}{l}\text { Proletariado } \\
\text { homogéneo sin } \\
\text { clases sociales, } \\
\text { igualdad abso- } \\
\text { luta. Solidaria, } \\
\text { interdepen- } \\
\text { diente. }\end{array}$ & $\begin{array}{c}\text { Totalitario: } \\
\text { propiedad y riqueza } \\
\text { comunes. Igualación } \\
\text { total. "La propiedad } \\
\text { individual es un } \\
\text { robo". }\end{array}$ & $\begin{array}{l}\text { REVOLUCIONA- } \\
\text { RIO: al servicio del } \\
\text { régimen, paradóji- } \\
\text { camente concebido } \\
\text { para reprimir toda } \\
\text { oposición. }\end{array}$ \\
\hline & $\begin{array}{l}\text { DEMOCRÁ- } \\
\text { TICO } \\
\text { (FABIANOS y } \\
\text { revisionismo } \\
\text { de E Berstein) }\end{array}$ & $\begin{array}{l}\text { Colectivo, } \\
\text { participativo, } \\
\text { comprometido } \\
\text { socialmente, } \\
\text { solidario }\end{array}$ & $\begin{array}{l}\text { Igualitaria y a la } \\
\text { vez pluralista, } \\
\text { prevalece la dig- } \\
\text { nidad humana. }\end{array}$ & $\begin{array}{l}\text { Interventor para } \\
\text { regular el mercado } \\
\text { (socializar los } \\
\text { medios de produc- } \\
\text { ción), Igualitarista } \\
\text { garante del bienestar } \\
\text { colectivo y los } \\
\text { derechos sociales, } \\
\text { económicos, cul- } \\
\text { turales. }\end{array}$ & $\begin{array}{l}\text { REFORMISTA: } \\
\text { Útil para la democra- } \\
\text { cia social y reconocer } \\
\text { la igualdad colectiva, } \\
\text { Compromete con } \\
\text { los otros y evita } \\
\text { privilegios. }\end{array}$ \\
\hline \multicolumn{2}{|c|}{$\begin{array}{l}\text { REPUBLICANISMO } \\
\text { (PARTICIPACIÓN) } \\
\text { (MIXTO: entre clásico y } \\
\text { moderno) }\end{array}$} & $\begin{array}{l}\text { Ciudadano } \\
\text { participativo en } \\
\text { la vida pública } \\
\text { Comprome- } \\
\text { tido con las } \\
\text { instituciones, } \\
\text { con NBS }\end{array}$ & $\begin{array}{l}\text { Ciudadanos } \\
\text { participativos } \\
\text { autogobier- } \\
\text { no, sociedad } \\
\text { conversacional, } \\
\text { construye públi- } \\
\text { camente. }\end{array}$ & $\begin{array}{c}\text { Interventor } \\
\text { Constitucionalista, } \\
\text { justicialista, de } \\
\text { bienestar garante de } \\
\text { libertades públicas y } \\
\text { exige deberes con el } \\
\text { Estado. } \\
\text { Servidor Público. }\end{array}$ & $\begin{array}{l}\text { POLÍ́TICO - GA- } \\
\text { RANTE: de la partici- } \\
\text { pación pública, } \\
\text { prioridad asuntos } \\
\text { públicos, la virtud } \\
\text { cívica, la seguridad } \\
\text { de la vida, bienes } \\
\text { y honra. Implica } \\
\text { disciplina ciudadana } \\
\text { sobre deberes y } \\
\text { derechos }\end{array}$ \\
\hline \multicolumn{2}{|c|}{$\begin{array}{l}\text { COMUNITARISMO } \\
\text { (Identidad - pertenencia) } \\
\text { (Taylor Ch, Walzer M) }\end{array}$} & $\begin{array}{c}\text { Miembro } \\
\text { perteneciente } \\
\text { etnopsicosocio- } \\
\text { culturamente a } \\
\text { una comunidad. } \\
\text { No individu- } \\
\text { alista }\end{array}$ & $\begin{array}{l}\text { Común-unidad } \\
\text { ciudadanos } \\
\text { con identidad } \\
\text { común } \\
\text { (Monocultural, } \\
\text { topofilia) }\end{array}$ & $\begin{array}{l}\text { Protector de la } \\
\text { identidad cultural. } \\
\text { Ideas de "bien } \\
\text { común" interno, } \\
\text { nacionalista, local. } \\
\text { Derechos de grupo }\end{array}$ & $\begin{array}{l}\text { Cultural } \\
\text { Nacionalista: re- } \\
\text { gionalista, localista. } \\
\text { Prevalece el sentido } \\
\text { de pertenencia, la } \\
\text { identidad cultural }\end{array}$ \\
\hline \multicolumn{2}{|c|}{$\begin{array}{l}\text { CONSERVADURISMO } \\
\text { (Tradición - herencia) } \\
\text { (Edmund Burke) }\end{array}$} & $\begin{array}{l}\text { Buen ciudadano } \\
\text { respetuoso de la } \\
\text { tradición, la he- } \\
\text { rencia y de la ley. } \\
\text { Las libertades } \\
\text { individuales son } \\
\text { más importantes } \\
\text { que la "igualdad" }\end{array}$ & $\begin{array}{c}\text { Implica jerar- } \\
\text { quía de grupos y } \\
\text { clases. es elitista: } \\
\text { algunas perso- } \\
\text { nas están mejor } \\
\text { preparadas que } \\
\text { otras, unas son } \\
\text { superiores y } \\
\text { otras inferiores } \\
\text { (la mayoria). }\end{array}$ & $\begin{array}{l}\text { No se hace ni surge } \\
\text { del "contrato", sino } \\
\text { de la historia, la tra- } \\
\text { dición, la herencia, } \\
\text { la costumbre y la } \\
\text { norma. Su poder } \\
\text { consagrado por } \\
\text { la costumbre y la } \\
\text { tradición se con- } \\
\text { vierte en autoridad. } \\
\text { Paternalista: las } \\
\text { masas necesitan de } \\
\text { los pudientes. }\end{array}$ & $\begin{array}{l}\text { Político-TRADI- } \\
\text { CIONALisTa: debe } \\
\text { hacer respetar las } \\
\text { buenas costumbres, } \\
\text { la tradición, la reli- } \\
\text { gión y la ley. Debe } \\
\text { mantener el orden } \\
\text { social y la justicia. }\end{array}$ \\
\hline
\end{tabular}

Fuente: Elaboración propia a partir de fuentes clásicas. 
Jairo Enrique Suárez Alvarez

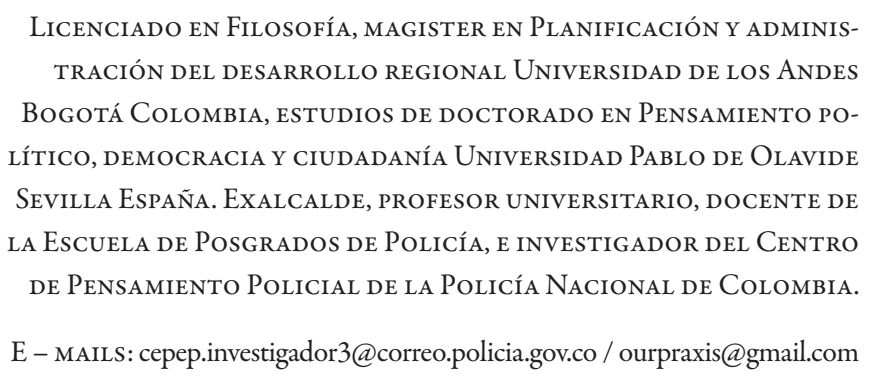

\section{REFERÊNCIAS}

AGAMBEN, Giorgio (2003). Homo Sacer: el poder soberano y la nuda vida. Valencia España: Pre-textos.

ARISTÓTELES (1985). Política. ESPASA - CALPE, Colección Austral. Madrid, España.

ARTETA, Aurelio y otros (2003). Teoría política: poder, moral y democracia. Madrid - España: Alianza Editorial

BAYLEY, D. H. (2002.). Eficacia policial y el respeto a los derechos de otros: ¿Es de suma cero? State University of New York-Albany. Volume: 2: Criminology \& Public Policy, Escuela de Justicia Penal. .

BAYLEY, D. (1994). Police for the future. New York: Oxford University.

BIELFELD, J. F. (1768). Instituciones Políticas. Madrid, Oficina de la Viuda de Manuel Hernández. Cuatro vols. 1768 Traducción castellana de Institutions Politiques, Paris.

BONNIN, C. J. (1834). Compendio de los Principios de

Administración. Madrid: Imprenta de José Palacios.

BUNGE, Mario (2009). Filosofía política. Solidaridad, cooperación y

Democracia Integral. Barcelona: Editorial Gedisa.

CAMACHO GUIZADO, Á. (1993). La reforma de la policía: realidades inmediatas y objetivos estratégicos. Revista Análisis Político No 19. , IEPRI Universidad Nacional may/agos.

CASTAÑO CASTILLO, Á. (1947). La policía, su origen y su identidad. Bogotá: Ed. Cahunt.

CASTILLO DE BOVADILLA, J. (1979). Política para Corregidores y Señores de Vasallos en Tiempos de Paz y Guerra, y para Jueces 
de paz, Eclesiásticos y Seglares, y sus Oficiales; para Regidores y Abogados, y del Valor de los Corregimientos y Gobiernos Realengos y de las Órdenes. Amberes, Juan Bautista Verdussen. 1704. Dos vols.

CASTILLO DE BOVADILLA, J. (1979) Código del buen gobierno hispanoamericano.

CEPOL (2007) European Police College. Perspectives of Police Science in Europe. Bramshill - United Kingdom.

DAMMERT, L. (2005). Reforma policial en América Latina. Quórum, revista de pensamiento Iberoamericano, No 12. Universidad de Alcalá. - Prevención comunitaria del delito en América Latina. ¿Discurso o posibilidad? (2004). - ¿Es necesario reformar las policías mexicanas?, Lecciones y desafíos de la experiencia latinoamericana, bien común, año 12. No (2006). .

DE FORONDA, V. (1801). Cartas sobre la policía. Biblioteca de Catalunya.

Delamare, N. (1622). Traité de la Police. Paris, chez Michel Brunet. Cuatro volúmenes, 1622 (1705-1713). [Hay una versión publicada en Amsterdam, que data de 1729].

FENTANES, Enrique (1972). Tratado de ciencia de la policía. Editorial policial. Buenos aires, República Argentina.

FENTANES, Enrique (1979). Compendio de Ciencia de la policía. (obra póstuma) Editorial Policial. Buenos Aires, República Argentina.

FERNÁNDEZ, Manuel Martin,(1990). La profesión de policía,Madrid, siglo Veintiuno de España.

FERNANDEZ DE VELASCO, R. (1927). "La noción de policía". Revista General de Legislación y Jurisprudencia.

FOUCAULT, M. (1991). "La Gubernamentalidad", en AAVV: Espacios de Poder, 1991a, pp. 9-26. Madrid: Las Ediciones de la Piqueta.

FRÜHLING, H. (1998). "Policía Comunitaria y Reforma Policial en América Latina: ¿cuál es el impacto? (2005)-"Modernización de la policía: Presentado al Foro "Convivencia y Seguridad Ciudadana en el Istmo Centroamericano" organizado por el BID,. San Salvador,.

FRUHLING, H. (1998). Modernización de la policía: Presentado al Foro "Convivencia y Seguridad Ciudadana en el Istmo Centroamericano. organizado por el BID, San Salvador, 2 a 4 de Junio de 1998. 
GASCÓN Y MARIN, J. (1961). "La ciencia de la policía". Estudios en homenaje a Jordana de Pozas. Madrid, Instituto de Estudios de Administración Local. .

GREENE, J. (2006). La policía de proximidad en Los Estados Unidos cambios en la naturaleza estructura y funciones de la policía. En justicia penal siglo XXI. US. Departamento de justicia.

GUERRERO OROZCO, Omar. (1996). Juan Enrique von Justi, Ciencia del Estado "Estudio introductorio". Toluca, IAPEM, INAP (México), INAP (España).

HINOSTROZA RODRIGUEZ, G. (2005). Un aporte epistemológico al estudio, e investigación para formular, desarrollar consolidar y difundir la doctrina y ciencia policial. Lima Perú: Ed. torre azul.

JARAMILLO URIBE, J. (2001). El pensamiento Colombiano en el siglo XIX. Alfaomega Editores Colombia.

JORDANA DE POZAS, L. (1944). "Los Cultivadores Españoles de la Ciencia de la Policía". Centenario de los Iniciadores de la Ciencia Jurídico-administrativa Española. Madrid, Instituto de Estudios de Administración Local.

JUSTI, Juan Enrique Gottlob de. Elementos Generales de Policía. Barcelona, Eulalia Piferrer. 1784. [Versión castellana de Grundsätze der Policeywissenschaft (1755), obtenida de la ediciónfrancesa de 1769].

LLERAS PIZARRO, Miguel. "Derecho de policía. Ensayo de una teoría general”. Tesis de grado. Editorial Cromos - Bogotá. 1943

LONDOÑO CÁRDENAS (2007) Fabio Arturo. Analectas para una filosofía policiaca. Bogotá: A.P.I. Impresores.

LONDOÑO CARDENAS, Fabio Arturo (2006) "Evolución del Derecho de Policía y Planteamientos Contemporáneos”. Bogotá: A.P.I. Impresores.

LOUBET DEL BAYLE, J. (1998). La policía. Acento Editorial, Madrid.

MALAGÓN PINZÓN, Miguel Alejandro (2007). Vivir en policía: una contralectura de los orígenes del derecho administrativo colombiano. Bogotá: Universidad Externado de Colombia.

MARQUARDT, Bernd (2007). Historia Universal Del Estado. Editorial Ibáñez. Universidad Nacional de Colombia 
MARTIN FERNANDEZ, M. (1990). "La profesión de policía", Centro de Investigaciones Sociológicas. Madrid, Siglo XXI de España editores S.A.). Profesión y organización: hacia un modelo Integral de Policía en España. Revista española de Investigaciones Socio jurídicas. REIS No 59.

NEISSA ROSAS, Guillermo (1990). El Estado policía. Bogotá: Litografía El Arco.

NIETO, Alejandro. (1976). Algunas precisiones sobre el concepto de policía. Revista de Administración Pública, 1976 SEP-DIC; XXVI (81), Página(s): 35-75.

OLIVAR BONILLA, Leonel (1995) El Derecho de policía y su importancia en la sociedad colombiana. Universidad Nacional de Colombia. Editado Linotipia Bolivar. Bogotá.

OSSE, A. (2007). Entender la Labor Policial, Recursos para activistas de derechos humanos. Madrid España. 13: 978 - 84 - 96462 - 18 - 2": Ed amnistía internacional.

PALACIOS CEREZALES, D. (2005). Policía, Opacidad y Ciencias Sociales. Política y Sociedad Vol. 42 Núm. 3: 7-13.

PINEDA CASTILLO, Roberto. (1988 - 1950) Derecho de policía. Ensayos. Plaza y Janés

PINEDA CASTILLO, Roberto. (1950) La policía: doctrina, historia y legislación. Editado por Concejo de Bogotá, Colombia.

PINEDA CASTILLO, Roberto (1997). Doctrina del derecho de policía en Colombia. Bogotá : Panamericana formas e impresos S.A.

POLICÍA NACIONAL DE COLOMBIA (2006). Poder, función y actividad de policía. Serie documentos y Departamentos y Municipios Seguros, doc. No 5.

RICO, José María, (1983). El poder discrecional de la policía y su control, en: José María Rico (comp.), Policía y sociedad democrática, Madrid, Alianza Universidad.

RICO, J. M. (2006). Las Reformas Policiales en América Latina: Situación, Problemas y Perspectivas. Instituto de Defensa Legal.

RICO, J. M. (1983). Policía y sociedad democrática. Madrid: Alianza universal. 
ROMA Y ROSSELL, F. (1768). Las Señales de la Felicidad de España y los medios para hacerlas eficaces. Madrid: Imprenta de Antonio Núñez del Valle.

TORRENTE Robles, D. (1999). Prevención del delito y futuro de la Policía. REIS: Revista Española de Investigaciones Sociológicas, 1999 ENE-MAR; (85).

TUDELA, P., \& HERRERA, A. (2005). Modernización policial: La relación de la policía con la comunidad como campo de gestión y referente de cambio en la Policía de Investigaciones de Chile. Policía de Investigaciones de Chile, Centro de Investigación y Desarrollo Policial.

UVALLE BERRONES, R. (1990). Origen, cobertura y objetivos de la ciencia de la policía. Revista de Administración Pública, Enero- abril No 76.

VAlERIOLA, T. (1978). Idea General de Policía o Tratado de la Policía. Madrid, [Edición facsímil de la original (1798-1805)].: Instituto Nacional de Administración Pública.

WALDMANN, P. (1996). Justicia en la calle: Ensayos sobre la policía en América Latina. Biblioteca Jurídica Diké Medellín Colombia. 